\title{
LESSONS FROM THE GREEKS - FROM CORPORATE ANATOMY TOWARD METAPHYSICS (PART I)
}

\author{
By: Seth Chertok*
}

\section{ABSTRACT}

The academic literature entails numerous anatomical studies on U.S. and comparative corporate law, mainly focused on dissections of the physical structures of corporate law. This Article makes a novel attempt to apply the ancient Greek metaphysical approach to a temporal, anatomical and functional study of Delaware, and in turn, with its findings of Delaware's innards, further addresses the longstanding debates on whether Delaware races to the top or bottom, and whether Delaware is unitary or divergent across space-time.

With a functionally focused approach inspired by Greek metaphysics, this Article maps out natural correspondences between the legal entities of corporate firms and the biological entities of society, such as a real person versus a legal person, individually and collectively. Furthermore, the current study lays bare the operating bowels of Delaware when faced with the increasingly vaster corporate structures of American society, along three major axes, the vertical (management versus shareholders), the horizontal (controllers versus minority shareholders) and the external (internalities versus externalities). In an attempt to shine light on the academic debate about the nature of Delaware's consciousness, this Article conducts a historical analysis on key events across seven epochs of American history, showing the influential factors that either swayed or preserved Delaware's postures, which have been as constant as pliant, like any well adaptive biological organism in a large ecosystem.

Through a temporal analysis as well as metaphysical study of the Delaware courts, the efficacy and efficiency of its judicial inner workings are quite apparent. There is sufficient evidence pointing toward a balanced structure of Delaware's jurisprudence, with a tenor of shareholder democracy and prosperity for all that races to the top, in other words, creating a win-win situation for different nodes of corporate firms yoked to the market like a colossal cobweb. Historical and functional evidence further show that 
despite the weathercock of the American economy and the ostensible state of flux with respect to Delaware's policies, the court has been consistently aiming at a fundamental unitary goal of establishing an economical equilibrium for the corporate market and society, as to be expected of the collective consciousness for a macrocosm compounded of equally mutualistic but antagonistic microcosms.

Last but not least, I apply the approach of comparative law to a deeper and broader question about the universality versus relativity of corporate laws in different societies. Spatial and temporal comparisons of legal infrastructures were conducted between the East and the West, the US and the EU, as well as some intra-American states such as Delaware, the MBCA and California. Once again, the cross-cultural studies reveal an interplay between intrinsic and extrinsic factors of legal consciousness around the world, time-wise and space-wise, which resonates with the simultaneous monistic and dualistic natures of Delaware and beyond.

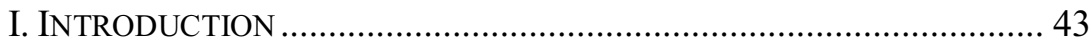

A. What is metaphysics? ............................................... 44

B. Utilities of a corporate metaphysis ................................ 45

C. Toward a metaphysics of corporate law ........................ 49

II. A BRIEF HISTORY OF THE FIRM ............................................... 50

A. First Epoch - 1890 - Great Depression ......................... 50

B. Second Epoch - Great Depression - Post-War Years...... 51

C. Third Epoch - Post-War Years - 1980s......................... 52

D. Fourth Epoch - 1980s - Early 1990s ............................. 52

E. Fifth epoch - Early 1990s - Early 2000s ....................... 53

F. Sixth Epoch - Early 2000s .......................................... 54

G. Seventh Epoch - Financial Crisis of 2008 - Present ....... 55

H. Conclusion.................................................................. 56

III. THE ANATOMY OF THE FIRM ................................................ 56

A. What are firms? .............................................................. 56

B. What do corporations do? .......................................... 57

C. Who is the corporation? ............................................. 58

D. The comparative perspective......................................... 64

IV. THE ANATOMY OF DELAWARE CORPORATE LAW ...................... 65

A. The Vertical Axis ........................................................... 66

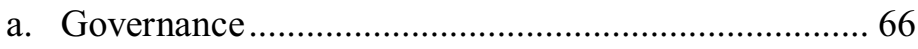

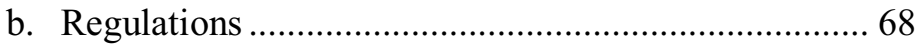

1. Duty of Care ........................................................ 69

2. Duty of Loyalty ................................................ 73

3. Duty of Corporate Monitoring ............................ 92 
B. The Horizontal Axis ........................................................ 94

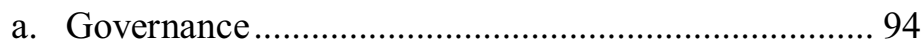

b. Regulations ................................................................ 95

1. Weinberger Doctrine - Sales and Oppositions ..... 97

2. Cleansing Weinberger .......................................... 99

3. Bypassing Weinberger........................................... 100

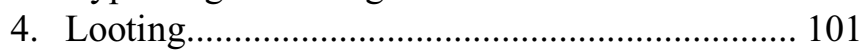

D. The External Axis............................................................ 102

\section{INTRODUCTION}

At the beginning of the Phaedrus, Socrates asks, "Where do you come, Phaedrus my friend, and where are you going?"1 In this Article, I reflect on this question, first as a legal scholar in its most general sense, and then in my field, as a corporate law scholar.

If we try to situate our current scholarly times into the history of ideas, both pragmatism and logical positivism seem highly influential. ${ }^{2}$ But in other times, humanity has trodden other intellectual paths. Classical metaphysics was not always a stranger to legal thinkers, in the larger historical picture. For example, not to mention the ancient world, even as late as the medieval educational period, metaphysics was an important part of higher education. "[T]he curriculum... came to include three Aristotelian philosophies - physics, metaphysics and moral philosophy."

\footnotetext{
* Seth Chertok, Visiting Associate Professor of Law at the University of Florida Levin College of Law. I would like to thank my corporate law mentors Professors David Skeel and Bill Carney for their consistent support of my teaching and legal scholarship over the years. In addition, I would like to thank the University of Pennsylvania Journal of Business Law for their continued support as well as dedication and diligence in the editing process.

1. Plato, Phaedrus, in Plato: Collected Dialogues 476, 476 (Edith Hamilton ed. 1999).

2. Pragmatism is "a philosophy that stresses the relation of theory to praxis and takes the continuity of experience and nature as revealed through the outcome of directed action as the starting point for reflection." CAMBRIDGe DictionARY OF PHILOSOPHY 730 (2d ed. 1999). "Three doctrines are associated with American pragmatism ... : that beliefs are hypotheses and ideas are plans of action; that ideas can be clarified by showing their relation to action; and that beliefs are true when they are successful guides for prediction and action." Richard H. Popkin, The Columbia History of Western Philosophy 592 (Richard F. Popkin et al eds., 1998) [hereinafter Popkin]. Logical positivism places an "emphasis upon sense experience generated [by] the doctrine of empiricism; namely, that all knowledge derives from the senses. The joint emphasis upon logic and experience explains why logical positive is sometimes called 'logical empiricism." Id. at 624.

3. Dimitris Romeo Havlidis, Medieval Education in Europe: A Force of Freedom and Submission (March 20, 2015), https://www.lostkingdom.net/medieval-education-in-europe/
} 
Metaphysics can be defined, "most generally, [as] the philosophical investigation of the nature, constitution, and structure of reality. It is broader in scope than science ... since one of its traditional concerns is the existence of non-physical entities . ..." "So understood, metaphysics was rejected by positivism on the ground that its statements are 'cognitively meaningless' since they are not empirically verifiable." In other words, it is seen as impossible to jump from visible empirical observations to more intelligible invisible forms.

Objections aside, Judge Posner has advocated for "the more ambitious and challenging task of mastering political and moral philosophy, economics, history, and other social sciences and humanities so that [the law academic] can discourse on large questions of policy and justice." ${ }^{6}$ If the legal academy is in a momentum of shifting toward more theoretical interdisciplinary areas, then why not metaphysics as well?

Hence, in this Article, I advocate for legal scholarship combining modern forms of Anglo-American empirical and pragmatic philosophical analysis, with notions of metaphysics borrowed from the Greeks. By combining the strengths of the ancients and moderns, what is invisible and visible, I believe that I can lay bare the fundamental mechanisms of both the firm and corporate law, and in turn answer some of the key debates that have plagued corporate law uncertainty.

\section{A. What is metaphysics?}

Any metaphysics of corporate law surely must derive from a larger metaphysics of existence. For these broad principles, I turn to the ancient Greeks.

In the earliest Pre-Socratic period at the very dawn of Greek philosophy, Heraclitus taught that "knowledge of the real" should focus on the "real constitution' (physis) of things by paying attention to their 'common' or universal aspect and by precise and patient sense observation and open-mindedness to possibilities (B101a, B18)."?

This patience, even though admittedly difficult and perplexing per the moderns, obviously implies considerable reflection on empirical experience

[https://perma.cc/DBZ5-9D3V].

4. CAmbridge Dictionary of Philosophy 563 (2d ed. 1999).

5. Id.

6. Richard A. Posner, The Present Situation in Legal Scholarship, 90 Yale L.J. 1113, 1119 (1981) (discussing the evolution of the history of legal scholarship in ever more theoretical directions).

7. Popkin, supra note 2, at 10. 
leading to the intelligible. Plato thus writes: "Well then, show me what, precisely, this ideal is, so that, with my eyes on it, and using it as a standard, I can say that any action done by you or anybody else is." ${ }^{\prime 8}$

As one so reflects on the universal, Heraclitus observed that "[the] real is unity, despite surface change and diversity, and even apparent opposites in nature, like night and day, winter and summer ... (B50)." ${ }^{9}$ In other words, the ever-changing empirical manifestations ultimately give rise to unitary principles. "[There is] a back-bending connection, like that of a bow or lyre." ${ }^{\prime \prime}$ I view Plato as adding some useful metaphysical markers, as follows: ${ }^{11}$

\begin{tabular}{|c|c|c|c|c|c|c|c|}
\hline Forms & One & Same & Invisible & Unchanging & Intellect & Truth & Knowledge \\
\hline $\begin{array}{c}\text { Sensible } \\
\text { Reality }\end{array}$ & Many & Different & Visible & Changing & Senses & Appearance & Belief \\
\hline
\end{tabular}

Much later, the Neo-Platonist Plotinus hypothesized that the highest intellectual goal was articulating the truth of what is absolutely necessary (intrinsic) as opposed to contingent (extrinsic). ${ }^{12}$

Philosophically, Plotinus argued that postulating Forms without a superordinate principle, the One, which is virtually what all the Forms are, would leave the Forms in eternal disunity. If this were the case, then there could be no necessary truth, for all necessary truths, e.g., $3+5=8$, express a virtual identity, as indicated here by the " $=$ ' sign. ${ }^{13}$

Hence, the goal of a metaphysics of corporate law should be to articulate what is unitary and intrinsic, even as extrinsic corporate law might ostensibly diverge in different sectors of space-time.

\section{B. Utilities of a corporate metaphysis}

At the highest level, it is important to build up a theory of corporate law

8. Plato, Euthyphro, in Plato: Collected Dialogues 174, 174 (Edith Hamilton ed. 1999).

9. Popkin, supra note 2, at 11.

10. Id.

11. $I d$. at 44 .

12. Id. at 105 ("Commonsensibly, there are two kinds of truth, contingent and necessary - for example, the contingent truth there are five coins in my pockets now, and the necessary truth that two plus three equals five.").

13. Plotinus, Stanford Encyclopedia of Philosophy, https://plato.stanford.edu/entrie s/plotinus/ [https://perma.cc/T43A-J3BG]. 
(with a focus on the standard Delaware public company), which scholars have noted is sorely lacking. ${ }^{14}$ Apart from filling this glaring theoretical gap, I believe that there are several tangible scholarly utilities in establishing a theoretical metaphysics of corporate law.

At a philosophical level, a metaphysics of corporations can humanize the corporation and show both how it mirrors us as people - and its place in nature and natural forces (also like us). It can also lead to a more fundamental understanding of the corporation, with an eye towards its dual visible and invisible characteristics, reminiscent of our cultural ancient ancestors. Hence, a metaphysics of corporate law could add an invisible eye to the kinds of anatomical studies, which focus on dissections of the physical structures of Delaware corporate law. ${ }^{15}$

Equally important, scholars for years have debated the race to the top versus bottom question, meaning whether Delaware law has catered to special interest groups, like powerful managers and controllers, and to some internal favoritism to the detriment of external counter-parties, like creditors, with non-value law, or whether Delaware has adopted a balanced and economical approach for all. ${ }^{16}$ Some scholars have undertaken empirical studies on this topic, but the data has likely been inconclusive. ${ }^{17}$ With this debate likely at a dead end, it is worth turning to a metaphysics of corporate law for answers.

Scholars have also, at least implicitly, debated whether the Delaware law is unitary or divergent. I have heard the Delaware judges effectively state that they are committed to timeless and continuing principles across judiciary transitions, even though they admit to making some innovative laws when needed (like say the Unocal doctrine). ${ }^{18}$ However, other scholars

14. See William W. Bratton, Jr., The New Economic Theory of the Firm: Critical Perspectives from History, 41 STAN. L. REV. 1471, 1471 (1989) ("Theories of the firm inform and undergird corporate law, but they only intermittently appear as principal points in corporate law discourse."); Edward B. Rock, Saints and Sinners: How does Delaware Corporate Law Work?, 44 UCLA L. REV. 1009, 1012 (1997) ("In part, my aim here is to highlight the absence of any developed theory to explain how corporate law works.").

15. See generally Reinier Kraakman et al., The AnAtomy of Corporate LAw, (2d ed. 2009) (consisting of several chapters providing physical anatomical studies of corporate law in a comparative law context) [hereinafter Anatomy].

16. See id., $\S 1.4 .3 \mathrm{n}$. 74 (setting forth much of the key scholarly literature on both sides in this race to the top versus bottom debate).

17. See Lucian Ayre Bebchuk, Federalism and the Corporation: The Desirable Limits on State Competition in Corporate Law, 105 HARV. L. REV. 1435, 1448-49 (1992) (analyzing the efforts of scholars' empirical studies to prove race to the top "value" as being inconclusive).

18. PLI Panel, Delaware Law Developments 2015. 
like Rock, ${ }^{19}$ Fisch $^{20}$ and Griffith ${ }^{21}$ see lots of indeterminacy and divergence. With this debate also at a standstill, it is worth turning to a metaphysics of corporate law, which could differentiate the unitary intelligible structures, from the ever-changing sensible.

Beyond theoretical debates, this study also has utilities for regulatory compliance. In the environmental regulation context, Ruhl and Salzman have pointed to the problem of regulatory information accretion. "Even if the mechanisms of regulatory erosion described above are taking place, the data presented... demonstrates that the forces of erosion have been overwhelmed by the processes of accretion." 22 Although an environmental law study, corporate law clearly also has a regulatory dimension, which can potentially accrete over time. ${ }^{23}$

The principal problem of regulatory accretion is that "in an unending but futile search for the perfect, regulators ensure constant regulatory confusion. ${ }^{24}$ Undoubtedly, regulations, even theoretically good ones, could confuse corporate regulated entities, like in the 1980s period of newly expanded insider corporate law regulations, with the Unocal, Revlon and Weinberger doctrines striking fear into the hearts of the insiders. ${ }^{25}$

Recent commentary sums up Delaware law's current situation as follows: 'The law governing the responsibilities of directors has

19. Edward B. Rock, Corporate Law Doctrine and the Legacy of American Legal Realism, 163 U. PA. L. REv. 2019, 2052 (2015) (noting that legal realists see "widespread indeterminacy in the law").

20. Jill E. Fisch, The Peculiar Role of the Delaware Courts in the Competition for Corporate Charters, 68 U. CIN. L. REV. 1061, 1076 (2000) (taking the position that "Delaware courts also apply the relevant legal standards in a fact and case specific manner. As a result, one court's determination that a particular course of dealing was reasonable under the relevant legal test provides little guidance to corporate actors about subsequent decisions applying the same legal test").

21. Sean J. Griffith, Good Faith Business Judgment: A Theory of Rhetoric in Corporate Law Jurisprudence, 55 DUKE L.J. 1, 5 (2005) (arguing "that the emerging duty of good faith is best understood as a rhetorical device rather than as a substantive standard").

22. J.B. Ruhl \& James Salzman, Mozart and the Red Queen: The Problem of Regulatory Accretion in the Administrative State, 91 GeO. L.J. 757, 782 (2003).

23. For example, there are regulatory "laws that are mandatory, leaving parties no option but to conform to them." Anatomy, supra note 15, at $\S 1.4 .1$ (explaining the differences between corporate law regulatory versus contractual functions).

24. Ruhl \& Salzman, supra note 22, at n. 224.

25. For example, "Van Gorkom triggered a backlash in corporate law over the fear that it would chill the American entrepreneurial spirit within the boardroom." Anne Tucker Nees, Who's the Boss? Unmaking Oversight Liability within the Corporate Power Puzzle, 35 DeL. J. CORP L. 199, 210 (2010). More abstractly, "[t]hese [new] rules represent surprises for those who complete transactions that become subject to subsequent challenge in an unexpected way and are now subject to new risks of liability for participants." William J. Carney, The Mystery of Delaware Law's Continuing Success, 2009 U. ILL. L. ReV. 1, 17. 
become so muddled that, incredibly, one can't get a consistent answer to the most basic corporate law question of how many fiduciary duties directors have--if you ask Delaware lawyers, the answer can range anywhere from two to five! ${ }^{26}$

To deal with this problem of regulatory confusion, Ruhl and Salzman offer compliance education as a solution:

The first focuses on ways regulators can increase their emphasis on compliance facilitation, primarily through good-old-fashioned education. While a salutary objective, this approach faces the two following problems: there is too much law on the books for the human mind to absorb; and, more pointedly, it is difficult to teach system-based compliance challenges that do not appear on the books. $^{27}$

Unlike in highly regulatory securities or environmental areas, each with sprawling federal agency regulations requiring virtually endless compliance education, less regulatory (and predominantly contractual) Delaware corporate law principles can be reduced to a few critical fundamental truths, as I will show. ${ }^{28}$ Hence, if anywhere, a metaphysics of corporate law could help alleviate the relatively narrow and limited range of regulatory problems in corporate law.

Finally, a metaphysics of corporate law could be useful for judges and policymakers. Haupt points out how comparative law could assist other states or nations turning to Delaware for lessons, ${ }^{29}$ which could, in turn, improve the efficacy of the corporate law regulatory free markets. For example, as the real seat doctrine erodes in the EU, perhaps this article could lay the groundwork for a value Delaware of the EU (which has not yet happened according to most European commentators). ${ }^{30}$ In America, even

26. Id. at 14 .

27. Ruhl \& Salzman, supra note 22, at 831.

28. Delaware corporate law, while having a regulatory dimension, is also quite contractual, and thus has fewer regulations than straight regulatory areas. Often, "corporate law simply offers a standard form contract that the parties can adopt, at their option, in whole or in part." Anatomy, supra note 15 , at $\S 1.4 .1$. But, I observe how some states' corporate laws could be somewhat more "regulatory."

29. See generally Klaus J. Hopt, Comparative Company Law, in THE OXFORD HANDBOOK OF COMPARATIVE LAW (Mathias Reimann \& Reinhard Zimmermann eds., 2006) (discussing the utilities of comparative corporate law). In particular, not all states can do what Delaware does, given the business specialization of Delaware's expert Court of Chancery. See Michael P. Dooley \& Michael D. Goldman, Some Comparisons between the Model Business Corporation Act and the Delaware General Corporation Law, 56 BUS. LAw. 737 , 765 ("The end result has been greater [Delaware] expertise and predictability than in other jurisdictions, especially given the limited number of judges to whom a case can be assigned.").

30. See Marco Ventoruzzo, "Cost-Based" and "Rules-Based" Regulatory Competition: 
if Delaware law is dominant, with multi-forum litigation on the increase, ${ }^{31}$ thus requiring a non-Delaware state court to decide on Delaware corporate law substantive matters, this study could possibly help those alternative states understand the fundamentals of the Delaware substantive approach, yielding improved outcomes.

Even for Delaware judges, the experts of their own jurisprudence, a comprehensive metaphysics of corporate law could have utility. History has shown how, when under pressure and facing urgent time constraints, Delaware courts occasionally adopt slightly imperfect new doctrines, which, although on the right track, require some recalibrations. For example, in the 1980s, while it was likely correct for the court to empower management takeover defenses at the height of corporate raider problems, ${ }^{32}$ Unocal $^{33}$ at first upheld management's anti-democratic coercive takeover defense, before only later fixing that pro-board mistake by adding more proshareholder democracy layers into the Unocal analysis. ${ }^{34}$ Hopefully, a metaphysics of corporate law could minimize these rare problems in the future.

\section{Toward a metaphysics of corporate law}

Aristotle gave a pragmatic approach for zeroing in on metaphysical inquiries, from which I draw.

Since knowledge is thought to consist in the knowledge of causes, Aristotle articulates a theory of four senses in which a thing might

Markets for corporate Charters in the U.S. and the E.U., 3 N.Y.U. J. L \& BuS. 91 (2006) (noting a lack of jurisdictional competition in the EU, even after the partial fall of the "real seat" doctrine).

31. "The two most dramatic corporate law changes of the past fifteen years have been the increasing federal role in corporate law and the advent of multi-forum litigation." David Skeel, The Bylaw Puzzle in Delaware Corporate Law, 72 Bus. LAw. 1, 4 (2016).

32. Takeovers had troubling consequences for corporate constituencies. Managers and employees were fired, pre-existing creditors subordinated and even shareholders squeezed in coercive bids. For example, Bratton observes how "the takeover challenged not only management's security of position, but also its discretionary power . ..." Bratton, supra note 14 , at 1528. "In the popular mind, Bergman says, lawyers who facilitated takeovers were just as responsible for the consequences as the raiders who counted the money. And Hollywood quickly cast the excess of Wall Street as Gordon Gekko, and called in the supporting cast of pin-striped lawyers." Lisa Stansky, M\&A is Back ... Only this time, mergers and acquisitions have a kinder, gentler face, 83 MAR A.B.A. J. 61, 61-62 (1997). Beyond all this, takeovers typically result in control shifts, and thus had possible anti-democracy implications for the Delaware "independent" corporation system.

33. Unocal v. Mesa Petroleum Co., 493 A.2d 946 (Del. 1985).

34. See infra Section IV (explaining the evolution of the Unocal doctrine). 
be explained: the formal cause (what it is), material cause (what it is made of), efficient cause (what brought it about), and final (what is its purpose). ${ }^{35}$

Given the difficulties of the first and last formal inquiries, I begin with a discussion of corporate history, then its organizational and legal matter, before turning to the more metaphysical inquiries of corporate law, first in Delaware and ultimately beyond Delaware.

\section{A BRIEF HISTORY OF THE FIRM}

To shine light on the academic debate about the nature of Delaware's consciousness, this Article conducts a historical analysis of key events across seven epochs of $20^{\text {th }}$ and $21^{\text {st }}$ century American history, showing the influential factors that either swayed or preserved Delaware's postures, which have been as constant as pliant, like any well-adapted biological organism in a large ecosystem.

\section{A. First Epoch-1890-Great Depression}

Bratton believes that the dominant modern "management-centered ... large corporate entities" ${ }^{\prime 36}$ came into existence around 1890, building up gradually to become the Berle-Means corporation, meaning a corporation that more and more separated shareholder capital and managerial control. ${ }^{37}$ In this period, widely dispersed shareholding "patterns ... enhanced management discretion ....",38

A couple of things drove all of this. "Actors on the capital markets withdrew from active participation in corporate management because they saw themselves as lacking in necessary expertise," 39 probably due to large organizations requiring a highly complex strategic science that specialized management, armed with inside information, alone can possess. Second, " $[\mathrm{u}]$ nder conditions of widely dispersed information and the need for speed in decisions, [managerial] authoritative control at the tactical level [became] essential for success." 40 Bainbridge calls this system "authority-based

35. Popkin, supra note 2, at 73.

36. Bratton, supra note 14 , at 1476.

37. Id. at 1487-88 ("Ownership of capital and control of the firm became completely separate.").

38. Id. at 1492

38. Id. at 1492 .

39. Id. at 1487 .

40. Stephen M. Bainbridge, Unocal at 20: Director Primacy in Corporate Takeovers, 
decision making, ${ }^{, 41}$ which is very similar to viewing managers as the heroic captains of their ships.

At this period in history, highly passive, widely dispersed shareholders could do very little to check and balance managers.

The conventional wisdom, moreover, held that investors had to go along whether they liked it or not: there was a collective action problem. Under the 'Wall Street Rule,' individual stockholders never found it cost-effective to challenge the tenure of an ineffective management group; selling the shares was the best course of action. This unspoken understanding governed management/investor relations until the late 1970s. ${ }^{42}$

What scholars call strong managers and weak shareholders obviously increased vertical agency problems, meaning situations where managers would too sharply pursue their own self-interest, against the interests of their shareholder principles. ${ }^{43}$ However, this epoch of growing, as well as more and more legitimized managerial power, concluded with the systemically threatening Great Depression. ${ }^{44}$

\section{B. Second Epoch - Great Depression-Post-War Years}

Presumably, the Great Depression was the first event to cast serious doubts on the credibility of firm management, resulting in a federal regulatory backlash. With this first round of post-depression major fears regarding the integrity of the firm, Bratton observes that, in the 1930s, the "federal government supplemented state law with the federal [proshareholder] securities laws. ${ }^{, 45}$ More important for state corporate law, in the post-war years, the American corporation regained its strong footing and reached unprecedented prosperity. In this period, scholars observed continuing growth and insulation from global competition. ${ }^{46}$

31 DeL. J. CORP. L. 769, 783 n. 63 (2006).

41. Stephen M. Bainbridge, Privately Ordered Participatory Management: An Organizational Failures Analysis, 23 DEL J. CoRP. L. 979, 1055 (1998).

42. Bratton, supra note 14, at 1492-93.

43. See Anatomy, supra note 15, at $\S 1.1$ (observing how "separation of ownership from control," in turn, "has sharpened the management-shareholder agency problem").

44. See Edwin F. Gay, The Great Depression, 10 Foreign AfF. 529, 529, 531 (1932) (detailing the state of national and international economic affairs following the American Depression); Eugene N. White, The Stock Market Boom and Crash of 1929 Revisited, 4 J. ECON. PERSP. 67, 68 (1990) (describing how vertical price drops on "Black Tuesday, October 29 " led to the Great Depression).

45. Bratton, supra note 14, at 1493.

46. See William Carney, Motivations for Mergers, in Mergers And Acquisitions 10 


\section{Third Epoch-Post-War Years - 1980s}

It is worth mentioning (not often mentioned in business scholarship) the rise of idealism in the 1960 s period, where there were various grass-roots movement struggles for social progress in a variety of areas, like, say, culturally in the arts, civil rights, anti-discrimination, or in more businessrelated areas, new laws like the neutral (neither favoring management nor hostile raiders) tender offer-focused Williams Act in the federal securities law, or even the rise of Justice Traynor's pro-consumer products strict liability (over the negligence theory) in state tort law (at least in California). Notably more relevant to corporate law, Cary, a famous law professor and former SEC Chairman, famously called out Delaware law's alleged race to the bottom in $1974,{ }^{47}$ which brought the matter of possible corporate law regulatory deficiencies to the attention of the courts and society.

Ideals in this period also coincided with new serious social problems brewing that threatened to destroy, or at least hinder, our society and prosperity. Although our American post-war prosperity years made it seem like the management was perfect and had unstoppable efficiency, blind trust in the firm (and management) ultimately culminated in several kinds of disastrous managerial inefficiency mistakes, such as fake earnings growth, conglomerate empire building, and poor investing strategies. ${ }^{48}$ However, during this pre-1980s period, these problems were largely masked by an illusion of perfect prosperity.

\section{Fourth Epoch - 1980s - Early 1990s}

That post-war American firm efficiency mirage was met with much pain during the takeover wave of the 1980s. ${ }^{49}$ In this hostile period, hostile raiders used evolving hostile tender offer tactics to take over inefficient corporations, with the idea of profiting from turning around firm inefficiencies. $^{50}$ Though in theory efficient value deals, these takeovers simultaneously created much pain for the various corporate constituencies. ${ }^{51}$

(4th ed. 2016) [hereinafter Carney].

47. William L. Cary, Federalism and Corporate Law: Reflections upon Delaware, 83 YALE L.J. 663 (1974).

48. See Carney, supra note 46, at 10-11.

49. See id. at 12 ("By the 1980s the hostile takeover had become commonplace."); Bratton, supra note 14, at 1520 ("In the more aggressive market for corporate control that appeared after 1980, almost all corporations became potential subjects for attack.").

50. See id. at 13 (noting that sell-offs of busted up conglomerates were worth more apart than whole).

51. See supra note 32 and accompanying text (highlighting various negative 
With a masked social problem suddenly uncovered and brought to light for all, management's credibility was once again cast into doubt. ${ }^{52}$ However, hostile raiders, viewed as the Gordon Gekkos of the world, engendered equal skepticism. ${ }^{53}$ As a result, the whole society was in a state of total confusion on the takeover question. Horizontally, controlling shareholders were now also seen with more suspicions after the freeze-outs of the $1970 \mathrm{~s}^{54}$

\section{E. Fifth epoch - Early 1990s - Early 2000s}

Relatively quickly, this first 1980s hostile takeover wave calmed down by the early 1990s. ${ }^{55}$ During this era, several new forces seriously increased corporate efficiency pressures and weakened vertical managerial power. First, with the stick, as actual hostile activity diminished, society was nonetheless left with the omnipresent specter threat of hostile activity, with a new market for corporate control. This meant that, should management revert to its inefficient ways, the markets would quickly notice and check management with future turnaround-oriented takeovers. ${ }^{56}$ Hence, the market for corporate control was highly correlated with a new emerging culture of corporate efficiency. ${ }^{57}$ Bratton observed how efficiency alleviated vertical agency problems. $^{58}$

Equally important, with the carrot, to foster this new culture of firm

consequences, such as the firing of managers and employees and the subordination of preexisting creditors).

52. See Bratton, supra note 14, at 1497 (noting that anti-managerialists cried out for a 'public' firm theory, analogizing corporate power to government power).

53. See supra note 32 and accompanying text (explaining that the excess profits on Wall Street were quickly type casted as Gordon Gekko, a regrettable enemy for corporations, in Hollywood).

54. See Christian A. Krebs, Freeze-Out Transactions in Germany and the U.S.: A Comparative Analysis, 13 GERMAN L.J. 941, 945 (2012) (noting an increase in controlling shareholder freeze-out activity in the early 1970s).

55. See Carney, supra note 46, at 13 (observing a decline in LBOs and raider financing in the early 1990s). Most deals then became friendly strategically-driven deals. See id. at 1821 (motivations for mergers).

56. See Henry G. Manne, Mergers and the Market for Corporate Control, 78 J. PoL. ECON. 110, 113 (1965) ("The lower the stock price, relative to what it could be with more efficient management, the more attractive the takeover becomes to those who believe that they can manage the company more efficiently.").

57. See id. at 112 ("A fundamental premise underlying the market for corporate control is the existence of a high positive correlation between corporate managerial efficiency and the market price of shares of that company."); Carney, supra note 46, at 13 (observing a change in board efficiency culture).

58. See Bratton, supra note 14, at 1517-18 (arguing that takeovers will remove inefficient managers). 
efficiency, rewards strategies (carrots) became more predominant. ${ }^{59}$ Some key examples of rewards strategies include stock options, restricted stock, and stock appreciation rights. ${ }^{60}$ Although critics argue that rising executive compensation packages resulted in possibly unjust compensation of managers, ${ }^{61}$ those mechanisms in theory better align the vertical interests of corporate managers with shareholders. ${ }^{62}$ If vertical interests are better aligned, then vertical agency and inefficiency problems are presumably further alleviated. ${ }^{63}$

\section{F. Sixth Epoch-Early 2000s}

If the 1990s are significant for weakening vertical managerial powers, the 2000s are significant for the rise of shareholder power, as the 2000s marked a shift in shareholders' natures. By 2000, fifty-one percent of all stock was owned by institutional investors. ${ }^{64}$ Institutional shareholders ${ }^{65}$ are larger as well as more powerful and coordinated investors, ${ }^{66}$ in comparison with the widely dispersed "ma and pa" public shareholders of the BerleMeans yesteryear. While in my view the top investors of yesteryear like the famous Benjamin Graham were always very intelligent, the old generation

59. See Anatomy, supra note 15 , at $§ 3.5$ (showing that rewards compensation is typically over half of management compensation packages)

60. See id. (describing types of rewards strategies).

61. See David I. Walker, A Tax Response to the Executive Pay Problem, 93 B.U. L. REV. 325, 327 (2013) (arguing that executive compensation contributes to growing wealth inequality).

62. See Anatomy, supra note 15, at $\S 3.5$ ("The theory, of course, is that optimallystructured pay packages can align the interests of managers with those of shareholders as a class."); Stephen Bainbridge, Director Primacy: The Means and Ends of Corporate Governance, 97 Nw. U.L. REV. 547, 577 (2003) ("Tying up the proportion of the director's personal wealth in stock of the corporation thus creates a hostage, aligning the directors' interests with those of shareholders."). But see Anatomy, supra note 15, at $\$ 3.5$ (showing that empirical literature is uncertain about the effectiveness of alignment of interest mechanisms).

63. See Anatomy, supra note 15, at $\S 3.5$ (Rewards can "substitute for direct shareholder monitoring when shareholders are dispersed.").

64. Norman S. Poser, Liability of Broker-Dealers for Unsuitable Recommendations to Institutional Investors, 2001 B.Y.U. L. REV. 1493, 1501 (2001).

65. See Theodor Baums, Taking Shareholder Protection Seriously? Corporate Governance in the United States and Germany, 53 AM. J. CoMP. L. 31, 58 (2005) (explaining that institutional shareholders include insurance companies, banks, mutual funds, pension funds, private equity and hedge funds).

66. See Anatomy, supra note 15, at $\S 3.1$ (showing that collective action facilitates the shareholder franchise). I observe that institutional investors can "coordinate" either through their trade group ISS, by discussing matters with one another under possible federal "proxy rules" exemptions or even in certain cases simply following the lead of another activist. 
lacked the musculature of today's institutional investors. Apart from the nature of institutional shareholders in themselves, they were likely greatly aided by the rise of the internet, further empowering their communicational means of both coordination and shareholder fiduciary duty lawsuits on governance matters. ${ }^{67}$ "[S]cholars have argued that institutional investor activism can give real teeth to shareholder control." ${ }^{68}$ All this, in theory, further alleviates vertical and (even horizontal) agency problems. ${ }^{69}$

Then, "[i]n the early 2000 s, society [nonetheless] witnessed the collapse of Enron. Not surprisingly, '[m]any legal scholars mark the fall of Enron as a momentous event in our legal and economic history." ${ }^{, 70}$ I observe that the collapse of Enron probably created both local corporate risks and even systemic risks to the broader society. Hence, Enron obviously resulted in another management discredit. Skeel observes the result of this period as "a marked expansion of federal regulation of corporate law [with SarbanesOxley], and an accompanying shrinkage of the portion of corporate law that is regulated by Delaware and other states." ${ }^{\text {"1 }}$

\section{G. Seventh Epoch - Financial Crisis of 2008 - Present}

The latest period is characterized by increasing non-Delaware alternative regulator pressures at both the federal and state levels. Roe has urged, "[c]onsider not just the horizontal relationship among competing states, nor just the possibility of a solitary Delaware as a pure monopolist, but also the vertical relationship of a vast federal authority that could, and occasionally does, displace the lawmaking of the little states below it." 72 Skeel thus observes that " $[t]$ he two most dramatic corporate law changes of the past fifteen years have been the increasing federal role in corporate law and the advent of multi-forum litigation." 73

Toward the end of the latter half of the first decade of the new millennium, American society witnessed the systemically threatening

67. I came across these internet implications notions in a discussion with students in my seminar.

68. Bainbridge, supra note 62, at 571.

69. See Anatomy, supra note 15, at $\S 2.1$ ("[A]gency problems in public corporations [were] exacerbated, due to the inability of the shareholder principals to coordinate and monitor agents, endowed with great discretion.").

70. Seth Chertok, Cracking the Problem of Finders - An Empirical and Computational Analysis, 51 WAKE Forest L. REV. 1021, 1073 (2016).

71. Skeel, supra note 31, at 2.

72. Mark J. Roe, Delaware's Politics, 118 HaRv. L. ReV. 2491, 2499 (2005).

73. Skeel, supra note 31 , at 4. 
financial crisis of $2008 .{ }^{74}$ Skeel notes how, "[a]fter the 2008 financial crisis, Congress further federalized state corporate law with the Dodd-Frank Act." ${ }^{, 75}$ "The more Congress intrudes on state corporate law — the more issues are dictated by federal law - the less Delaware incorporation has to offer. Delaware therefore has a strong interest in keeping Congress at bay." 76

Another key event in the last decade is the presence of state multi-forum litigation. "In the past decade, the shareholders of Delaware corporations have brought an increasing number and percentage of their lawsuits against corporate directors or officers in states other than Delaware." 77 Skeel observes that " $[w]$ hat sets Delaware apart is its sophisticated corporate law judiciary and its rich supply of precedents on any conceivable corporate law issue." 78 Parallel to the federal law issue, Delaware therefore has a strong interest in keeping multi-forum litigation at bay. ${ }^{79}$

\section{H. Conclusion}

Ultimately, what appears to drive forward state corporate law's historical momentum are key events that affect regulated entity internal governance (money and power) relationships, like ambiguous raiders coming into the corporation, or the rise of institutional investor more muscular shareholders. Or, indirectly, innovations such as the internet, which changed the communicational dynamics among those who are inside the corporation, could also be highly relevant. Beyond the regulated entity side, corporate law is also shaped by regulator pressures, with the rise of both alternative state and federal checks on Delaware law.

\section{THE ANATOMY OF THE FIRM}

\section{A. What are firms?}

Virtually all kinds of firm entities aggregate capital to profit from valuable goods and services. However, only corporations have five business characteristics as a default - "(1) legal personality, (2) limited liability, (3)

74. See Chertok, supra note 70, at 1073 (demonstrating how the financial crisis posed systemic risks).

75. Skeel, supra note 31, at 2.

76. $I d$. at 15 .

77. Id. at 2 .

78. Id. at 20 .

79. See id. ("If shareholders started filing their lawsuits in other states, the Delaware engine would soon begin to struggle."). 
transferable shares, (4) centralized management under a board structure, and (5) shared ownership by contributing capital." 80 "Together, they make the corporation uniquely attractive for organizing productive activity [especially for the typical Delaware public company]." ${ }^{\prime 1}$ Of course, corporations could at times "contract" away from certain of such "defaults," but that typically would not happen in the standard public company, except for certain stock transfer restrictions. ${ }^{82}$

\section{B. What do corporations do?}

What a corporation does is fundamentally its spirit. In short, corporations use their structures to contract either internally or externally. Internally speaking,

[i]n the economics literature, a firm is often characterized as a 'nexus of contracts'.... It is often invoked simply to emphasize that most of the important relationships within a firm - including, in particular, those among the firm's owners, managers, and employees - are essentially contractual in character, and hence based on consent, rather than involving some form of extra contractual command-and-control authority. ${ }^{83}$

I observe that most internal contracting is simply "big boy" corporate governance agreements on the allocation of money and power issues.

Externally speaking, firms are also nexuses for contracts, "in the sense that a firm serves, fundamentally, as the common counterparty in numerous contracts with suppliers, employees, and customers, coordinating the actions of these multiple persons through exercise of its contractual rights." ${ }^{84}$ These "nexuses" are good to the extent that they build goodness, prosperity, freedom, stability and balance for the larger society.

Apart from these corporate internalities nexuses, at times corporations can also impose externalities, most of which are unintentional, but occasionally intentional criminal scandals can arise. In an imperfect world invariably filled with some amount of unfortunate accidents, unintentional externalities, per economists, can either be optimal or sub-optimal (or reasonable versus unreasonable), essentially meaning whether or not, on

80. Anatomy, supra note 15 , at $\S 1.2$.

81. Id.

82. For example, securities laws in certain cases require restricted stock after offerings. Sometimes, director and officer stock is also restricted to create better alignment of interest incentives in rewards compensation.

83. Id. at $\S 1.2 .1$.

84. Id. 
balance, the externalities are truly reasonably necessary (done in the best possible, most ethical and safest way), while still achieving (and hopefully not significantly over-deterring) imperative utilities that build goodness, prosperity, freedom, stability and balance for the larger society (and avoiding some of the social problems from prior, less prosperous eras). ${ }^{85}$ In simple language, economists believe that some externalities are just life, but too much are unethical and even "net" uneconomical.

\section{Who is the corporation?}

A question of where more work is to be done is not "what does the firm do?" but rather "who is the firm?" With a functionally focused approach inspired by Greek metaphysics, this Article maps out natural correspondences between the legal entities of corporate firms and the biological entities of society, such as a real person versus a legal person, individually and collectively.

Many have relationships with the firm, but firm specialists (particularly in Delaware) naturally categorize those parties into internal versus external and view only the internal parties as part of the firm. Delaware law tends to view only two flavors of internal parties, along what I call the vertical axis (management versus shareholders), and the horizontal axis (controllers ${ }^{86}$ versus minority shareholders as well as "class" versus "class"). Outside of these two internal axes, virtually all other parties with firm relationships are viewed as situated along a separate external axis, such as creditors, preferred stock, employees, suppliers, customers, charitable beneficiaries and even the government/society.

Apart from the corporation being its people, the corporation is also an entity and hence legal person unto itself. Obviously, corporations can own property and contract like real people. Moreover, corporations can receive Constitutional governmental protections, at times, like a real person. For

85. Economists usually argue for the law promoting "optimal" externalities (on the whole) and only deterring externalities when "sub-optimal." Different types of temperaments, of course, might have differing opinions on balancing results, depending on whether they are strictly economics oriented or gravitating toward more common sense activist ideals of fairness (even with the latter being somewhat amorphous).

86. Delaware courts view control either as majority ownership, or a significantly high percentage falling slightly shy thereof, but with what I call muscling or dominating, meaning perhaps telling management what to do, or other overly aggressive tactics in conflicted situations. See, e.g., Kahn v. Lynch Communication Systems, Inc. 638 A.2d 1110, 1114 (Del. 1994) ("For a dominating relationship to exist in the absence of controlling stock ownership, a plaintiff must allege domination by a minority shareholder through actual control of corporation conduct.”). 
some time, corporations have had Fifth Amendment "Takings" property rights protections. More recently, the Citizens United case has even held that a corporation is a legal person for First Amendment purposes, with rights to speak freely like a regular person. ${ }^{87}$ Whatever one's attitude toward the personality of corporations, ${ }^{88}$ it is important to consider why corporations might anatomically be viewed as real people, unto themselves, apart from the aggregation of their inner individuals separately?

Metaphysically, it seems that an aggregation of bodies will often have body-like anatomical structures. The body-like cells form the human body and the aggregated human bodies form a kind of gestalt super-body. Ventoruzzo et al. observed that "[t]he word 'corporation' comes from the Latin word 'corpus,' meaning 'body." " 89 But why? First, a corporation is to some extent a derivative of us, who made the corporation, hence it makes sense that it would resemble us. Second, Heraclitus did observe that existence itself would reflect "an ordered, rational and unified reality." Hence, in theory, one sphere could cross-correspond to another (in a prior article, I observed how economic systemic risks likely work just like a physical network of metal discs and chains, and Judge Andrews was famous for his waterbodies allegory revealing the fundamental nature of proximate causation in Palsgraf). ${ }^{91}$

I observe that the corporation has observable very similar real personlike anatomical structures in many respects. Most obviously, corporations have a life process, just like a real person. They are birthed into this world with their "formation," 92 then have their life with their "legal personality" (discussed above) and one day perhaps their death should "liquidation" be

87. See Citizens United v. Federal Election Commission, 558 U.S. 310, 315 (2010) ("[T]he Government may not suppress political speech based on the speaker's corporate identity.").

88. See Anthony J. Gaughan, The Futility of Contribution Limits in the Age of Super PACS, 60 DrAKE L. ReV. 755, 774 (2012) (observing Citizens United as a very controversial position, possibly opening the floodgates of special interest groups). My belief is that the majority and dissents in that case basically split on the issue of corporate aggregations of people having their free rights to speak (just like an individual person or even a political party), versus those powerful purely business-driven aggregations (which in contrast to political parties are not truly ideological in competence) possibly hindering the democratic political process, as, say, President Jefferson long ago might have feared.

89. Marco Ventoruzzo et al., Comparative Corporate LaW, 131 (2015 ed.).

90. See Popkin, supra note 2, at 11.

91. See Chertok, supra note 70; Palsgraf v. Long Island R. Co., 162 N.E. 99, 103 (N.Y. 1928) (using the analogy of disturbing a body of water to describe how multiple causes can have overlapping effects).

92. Del Code. Ann. Tit. $8 \S 101$ (charter filing creates incorporation). 
triggered. ${ }^{93}$ In contrast to humans, corporations are conditionally immortal, should "liquidation" never be triggered.

Once birthed, if we want to understand the corporate body, the starting point is to intuit that bodies are always organized, with certain prominences and functionalities, in their skeletons and organs. The corporate body is no exception. While its anatomy in many respects is very much human-like, as one might imagine for an alien species, there are some divergent corporate biological rules. Namely, a corporation has much fewer core bones than a human, and given corporate organs can have simultaneously overlapping functionalities.

First, I view the skeleton of the corporation largely along the lines of its internal vertical and horizontal axes, forming a delta shape if one were to draw it out. ${ }^{94}$ These vertical and horizontal axes can be thought of as "connected" with fragile joints rather than hard bones. I say joints since empirically those links are very vulnerable spots, and hence the focus of the lion's share of corporate regulations. ${ }^{95}$ If iterating corporate law issues, one could even imagine Da Vinci's famous icosidodecahedron drawing (where "each face is augmented with a pyramid composed of equilateral triangles"). ${ }^{96}$

Bodies always have skin delimitations, dividing the inside from the outside. The corporate skin is a mix of limited liability ${ }^{97}$ plus entity shielding. ${ }^{98}$ Easterbrook \& Fischel observe how much all this does for the corporate system, by facilitating wealth and economics efficiency for the society. ${ }^{99}$ With this corporate skin in place, external creditors usually cannot

93. Del Code. Ann. Tit. $8 \S 275$ (dissolution statute).

94. Of course, for the Germans, who see workers on the inside (which I will discuss in part II), there could be a different kind of delta formation. One might think of a bee farm. Should we view the farm only in terms of the worker bees bringing in honey and the bee keeper distributing it out, or also as the drones working with that honey?

95. See Anatomy, supra note 15, at $§ 2.1$ ("Indeed, much of corporate law can usefully be understood as responding to three principal sources of opportunism: conflicts between managers and shareholders, conflicts among shareholders, and conflicts between shareholders and the corporation's other constituencies, including creditors and employees.").

96. See Dirk Huylebrouck, Lost in Triangulation: Leonardo da Vinci's Mathematical Slip-Up, SCIENTIFIC AMERICAN, (Mar. 29, 2011), https://www.scientificamerican.com/article /davinci-mathematical-slip-up/ [https://perma.cc/AXA5-ZLWQ] (describing an error that da Vinci made in his polyhedron drawing for Luca Pacioli's book); George W. Hart, Leonardo da Vinci's Polyhedra, https://www.georgehart.com/virtual-polyhedra/leonardo.html [https:// perm.cc/M79E-34FA] (describing da Vinci's drawings of polyhedral).

97. See Anatomy, supra note 15 , at $\S 1.2 .2$ (creditors typically have claims only against the firm and not the individual shareholders).

98. See id. ("Entity shielding protects the assets of the firm from the creditors of the firm's owners. ...").

99. Frank Easterbrook \& Daniel R. Fischel, Limited Liability and the Corporation, 52 U. 
go after internal parties, and internal creditors usually cannot go after the corporation. ${ }^{100}$ But like with human skin, that corporate skin is not made of metal, and thus could be pierced in extreme cases under, for example, the doctrine of piercing the corporate veil. ${ }^{101}$

Inside the corporate body, different firm actors have different organlike functionalities.

The shareholders function as the mouthpiece of the corporation. Managers are always subject to periodic accountability at shareholder votes. ${ }^{102}$ Hence, management must ultimately bow to the voice of its people. Further, today, as shareholders have become more institutional, ${ }^{103}$ those more powerful and coordinated shareholders have essentially also become the firm's muscles. As I show later, one would expect institutional shareholders both to make trouble for managers on bad strategic decisions and to influence independent committees to fight for more shareholder short term value in vertical (or even horizontal) disloyal deal situations. Although rare in the United States, some corporations might have controlling shareholders, who can be thought of like a queen bee in a bee colony, controlling by herself the shareholder voice of the corporate people.

Managers function as several kinds of organs all at once. First, managers are the corporate eyes. Only managers should have full access to seeing the proprietary inside information of the firm. ${ }^{104}$ Equally important, managers function as the corporate brains. Only managers are the true intellectual masterminds of their strategic long-term value science. ${ }^{105}$ The combination of eyes and brains make management the perfect captains of their ships.

Management can also function as the corporate immune system. As the

CHI. L. REv. 89 (1985) (explaining the economics theories behind corporate limited liability).

100. See Anatomy, supra note 15 , at $\S 1.2 .2$ ("Together, they set up a regime of 'asset partitioning' whereby business assets are pledged as security to business creditors, while the personal assets of the business's owners are reserved for the owners' personal creditors.").

101. See id. at $\S 5.3 .1 .2$ ("[A]ll our jurisdictions permit courts to 'pierce the corporate veil' in extreme circumstances; that is, to hold controlling shareholders or the controllers of corporate groups personally liable for the company's debts.").

102. See id. at $\S 1.2 .4$ (stating that the board is typically elected by the shareholders).

103. See supra note 64 and accompanying text (describing the recent increase in the number of institutional investors).

104. See Bainbridge, supra note 62 , at 558 (observing how no other corporate constituency has insider competence).

105. See James Mackintosh, In the Long Run, Fear of Short-Termism is Mostly Bunk, WALl StReET J. (May 10, 2018, 12:57 PM), https://www.wsj.com/articles/in-the-long-runshort-termism-backlash-is-mostly-bunk-1525969223 [https://perma.cc/X38U-6GKD] (arguing that managers are functional as long term strategists, even though they are mistakenly viewed as short term oriented). 
Revlon court noted, until Revlon mode kicks in, ${ }^{106}$ managers are the natural "defenders of the corporate bastion."107 That raises the question: what is such a defender exactly? Facing an active hostile takeover threat, management might adopt takeover defenses, just like a sick human's immune system might kick into an acute mode. Moreover, even in non-acute situations, ordinary strategic decisions could be viewed as fundamentally defensive, with the advent of the market for corporate control threat, ${ }^{108}$ since efficient decisions ultimately keep hostile raiders at bay. However, the corporate immune system does not function exactly like a human's, since outsider corporate invader organisms, if the firm is inefficient, can step in to turn around inefficiencies. Hence, the corporate outsider invader has legitimacy at times, thus society might want less corporate immune system response. But even then, those inefficiency turnarounds often involve painful pressures on so many corporate constituencies. ${ }^{109}$ Thus, confused about cure and disease, the corporate immune system needs to be regulated carefully with the Delaware law of takeover defenses. ${ }^{110}$

Interestingly, managers can even function as the mouthpiece and heart of the corporation. Once elected, First Amendment corporate "speech" rights are in management's discretion - and management's judgment will also prepare many firm public disclosures. Further, many corporate acts of magnanimity toward the "external" axis are legally merely "discretionary," hence management will often have the ultimate say on corporate "good will" judgments.

In any insider (vertical or horizontal) disloyalty situation today, there should be liver-like cleansing. Putting state together with federal and listing rules, cleansing is used not only for conflicted deals, but also for thorny areas such as audit, nomination and compensation committees. ${ }^{111}$ In strictly state

106. See infra Section IV (analyzing corporate structures under Delaware law).

107. Revlon, Inc. v. MacAndrews \& Forbes Holdings, Inc., 506 A.2d 173, 182 (Del. 1986).

108. See supra Section II (outlining the historical development of Delaware corporate law).

109. See supra note 32 and accompanying text (discussing the potential issues arising from corporate takeovers).

110. See infra Section IV (analyzing corporate structures under Delaware law).

111. The law does not always use a liver for every problem, but only in problematic possibly tainted areas, like say state corporate law insider disloyalty. See infra Section IV. Under federal law, "Sarbanes-Oxley dictates independence requirements for the audit committees of public companies." Joseph Mead, Confidence in the Nonprofit Sector Through Sarbanes-Oxley-Style Reforms, 106 MicH. L. REV. 881, 888 (2008). “The NYSE and NASD AQ went beyond SOX: each exchange required that listing companies have (1) wholly independent nominating/corporate governance and compensation committees and (2) a majority independent board." Usha Rodrigues, The Fetishization of Independence, $33 \mathrm{~J}$. 
law disloyalty situations, depending on the precise nature of the conflicts, that cleansing process consists of either an independent committee of disinterested directors, disinterested minority shareholders, or both. ${ }^{112}$

One issue that has arisen is whether the corporate liver can also cross over into being the corporate eyes and brains, at least to some extent. With disinterested parties typically lacking insider expertise, ${ }^{113}$ having no (or little) significant stakes in the firm (in contrast to insiders with rewards packages) ${ }^{114}$ and considerable outside distractions, ${ }^{115}$ those cleansing structures could work purely like livers in the human body. They might well clean out insider taint, but not necessarily with more intelligence. To make matters worse, some scholars have even expressed some gadfly consternations in the face of potential managerial disharmony problems. ${ }^{116}$ However, there are also scholars who believe that there is smartness in independence, since "[independent directors] look to outside performance signals and are less captured by the internal perspective." $" 117$

No organism would be complete without a heart. Here, the court is the ultimate conscience of the firm. Rock sees the court as fundamentally moralistic. "Why might it be that Delaware corporate law shies away from using 'laws' to deter bad behavior and leans, instead, towards morality

CORP. L. 447, 458 (2008).

112. See infra Section IV (analyzing corporate structures under Delaware law).

113. See Lisa M. Fairfax, The Uneasy Case for the Inside Director, 96 Iowa L. ReV. 127, 179-80 (2010) (arguing that insiders have more context for information).

114. See supra note 59 and accompanying text.

115. See Jeremy C. Kress, Board to Death: How Busy Directors Could Cause the Next Financial Crisis, 59 B.C. L. REv. 877, 899 n.129 (2018) (observing the quantity of disinterested party outside distractions and its possibly negative effect on firm value).

116. See Ventoruzzo, supra note 89, at 151 ("In the last few years, if not decades, the number and relevance of independent (and/or outside) directors have risen in virtually all developed nations. Is this desirable? Does this create the risk of a less collective board?").

117. See Jeffrey N. Gordon, The Rise of Independent Directors in the United States, 19502005: Of Shareholder Value and Stock Market Prices, 50 STAN. L. Rev. 1465 (2007). If a corporation believes in the liver as also the eyes and brains, it should think about ways to cultivate the smartness of such organs. There are a few possible solutions. First, I could imagine making "independent" directors privy to more "inside information." Then, I could imagine a corporation hiring a lot of "outside" strategic and financial experts, who would have the skills to dissect that "inside information." Then, insiders and outsiders could work together on non-conflicted regular (or straight "strategic") and even Unocal "defense" decisions (a mix of "strategic" and "conflicted"), with vigorous Q\&A about one another's views. Having limits on the "outsider's" other time and business commitments could help mitigate over-extendedness problems. Finally, the corporation could potentially consider economics "alignment of interest" mechanisms/incentives to induce "competence." Of course, the more one tries to solve the "smartness" problem of "outside" directors, perhaps the more such directors start to cross "the line" toward resembling "insiders." 
tales?"118 The court then essentially has the ultimate mandatory say of what is fair (versus unfair) inside the corporation. Apart from legal compulsion, perhaps corporations also voluntarily trust ${ }^{119}$ in the Delaware courts, who can and do combine fairness with terrific economics sense, ${ }^{120}$ just like how many corporations voluntarily adhere to some notion of corporate good will. ${ }^{121}$ It is also worth noting that the courts simultaneously appear to function like the human endocrine system, carefully regulating the balance of the corporate fundamental forces described in Section V.

In recent years, many have become interested in the gender, ethnic, religious, sexual orientation and other diversity aspects of those who are playing their corporate managerial roles. ${ }^{122}$ Apart from being an antidiscrimination matter in itself, perhaps different from the human body where most organ functionalities possibly share one gender and ethnicity, diversity of corporate people, to some scholars, is relevant in terms of actual organ functionalities. For example, Branson has argued that he believed that female directors had superior "competences" on certain business issues. ${ }^{123}$

\section{The comparative perspective}

The basic parts of the firm body remain remarkably constant throughout both space and time, with a few exceptions. First, internally, in some

118. Rock, supra note 14, at 1101. However, as I show in Part II, the court will not be bogged down sanctimoniously, if things are ultimately good, in the big picture.

119. The decision to be governed by Delaware corporate law is typically based on corporation state "formation" choices.

120. Perhaps some insurgent shareholder corporate social responsibility proposals seek fairness but have a non-economically oriented agenda at times. While such proposals may be gaining momentum, they "do not frequently garner a majority of support from voting shareholders." See Matthew J. Petrozziello, 13 Rutgers Bus. L. REv. 22, 29-31 (2016) ("CSR activists utilize shareholder proposals to leverage their way into constructive dialogue with corporate management regarding social issues."). Apart from such proposals, some social responsibility funds now might also exert some limited fairness pressures on corporations, via the markets. See Charles Schwab, Socially Conscious Funds List (2018), ht tps://www.schwab.com/public/file/P-9561751/ [https://perma.cc/MXT9-9PJM] (describing the ethical criteria of how some socially conscious funds invest).

121. By good will, I observe how many firms will often voluntarily try their very best to enhance relationships with various corporate constituencies, like employees, customers, suppliers, creditors, etc., all of which (at least to some extent) should clearly add long-term value to any business.

122. Debates have ensued about the role of state and federal law in "mandating" such board diversity, or at least promoting, say, public company board diversity "disclosures." See, e.g., Douglas M. Branson, Initiatives to Place Women on Corporate Board of Directors - A Global Snapshot, 37 J. CORP. L. 793 (2012).

123. See id. (advocating for female emotional sensitivity, law-abidingness and consumer preferences expertise). 
countries (like Germany), there is a two-tier board structure (one tier for long-term oversights and another tier for day-to-day management), which could potentially elongate the top delta joint, like a stretched forehead. ${ }^{124}$ Moreover, apart from the delta parts themselves, the power relationships among those parts can also shift in space and time. For example, in space, controllers are both more powerful and common in Europe and Asia than in the United States and the U.K. ${ }^{125}$ And within the United States, over time, managers have somewhat weakened (yet still remained fairly strong) while institutional shareholders have risen up by an order of magnitude. ${ }^{126}$

Second, externally, different societies can philosophically view certain grey area corporate constituencies (like employees or preferred shareholders) as either internal or external, which I discuss in Part II.

\section{THE ANATOMY OF DELAWARE CORPORATE LAW}

Before addressing the metaphysics of corporate law, I now take on the task of simplifying the anatomy of corporate law by focusing on the Delaware corporate law regulation of the essential parts of the firm. In short, corporate law basically only has to modulate key axes governance (money and power) issues, but more so internally than externally. Hence, I reduce the gist of Delaware corporate law fiduciary duties to a simple series of maxims. That the free markets should be honored in apportioning money and power governance matters in the delta (and to a large extent, even in the external lands), thus letting each do as he pleases (freely) with his quasinatural given market powers (property or contractual), unless abusive or oppressive, with a typical steeper abuse threshold externally versus internally. If the law desires to get involved, all jurisprudence usually relates to some form of asking whether one node should ether facilitate or oppose the other?

124. See Jens Dammann, The Mandatory Law Puzzle: Redefining American Exceptionalism in Corporate Law, 65 HASTINGS L.J. 441 (2014) (pointing out how the German two-tier structure could have implications, such as slowing down (and thus deterring) "takeover" attempts, or helping founders with closely held business succession planning).

125. See Sofie Cools, The Real Difference in Corporate Law Between the United States and Continental Europe: Distribution of Powers, 30 Del. J. CORP. L. 697, 698 (2005) ("The Berle and Means corporation, with many dispersed shareholders and control in the hands of management, is not a worldwide phenomenon. Outside Anglo-Saxon jurisdictions, different corporate ownership structures in which controlling shareholders have a large stake in the company's equity predominate.").

126. See supra Section II (outlining the historical development of Delaware corporate law). 
Both vertical and horizontal relationships (and their agency problems), or body joint problems, are primarily dealt with either by governance or regulations. Governance generally consists of default terms (on corporate money or power issues), subject to contractual flexibility deviations in the corporation's governance documents (like the charter or bylaws), unless inequitable. ${ }^{127}$ Hence, governance is flexible but not $100 \%$ flexible. Regulation refers to mandatory rules that must always be obeyed, without flexible contracting rights. ${ }^{128}$ One could think of regulations as the court's fairness bottom line on governance (money and power) matters. That rigidity was, and still is, balanced by opposing shield and carrot forces (described below). Hence, regulations of so many forms are rigid but not $100 \%$ rigid.

\section{A. The Vertical Axis}

\section{a. Governance}

Governance is controlled by quite a few cosmic vertical tensions and, to a lesser extent, sometimes even some politics. ${ }^{129}$ Obviously, a corporation requires a fundamental opposition between some level of mandatory Section 141(a) centralized management powers in large complex corporations (especially on pure property decisions) ${ }^{130}$ versus a corresponding mandatory shareholder franchise in some form ${ }^{131}$ and other rights (especially on certain key fundamental matters). ${ }^{132}$ As usual, that balance is achieved through a

127. See Anatomy, supra note 15 , at $\S 1.4 .1$ (observing that corporate law default terms are those that most parties would be expected to choose, subject to contracting).

128. See id. (distinguishing mandatory regulations from contractual corporate law).

129. See Skeel, supra note 31 (analyzing the proxy access and shareholder litigation bylaws debates in Delaware law).

130. My experience is that these encompass matters such as certain strategic decisions, bylaws amendments, stock issuances, dividends and stock repurchases, subject to certain exceptions.

131. States take differing views as to what matters require "voting," and then exactly what "quorum" and "percentage" of shareholder approval is needed as well as whether any "class" should have "voting" and "veto" rights (which, in certain cases, can be subject to some limited degree of "contractual" modifications). Of course, courts also want qualitatively fine voting, like with full disclosures, no coercion, etc. See Gantler v. Stephens, 965 A.2d 695 (Del. 2009) (state law duty of disclosure).

132. See Anatomy, supra note 15 , at $\S 7.1$ ("Although there is no single set of characteristics that marks the limits of the board's power to decide unilaterally, either across jurisdictions or within them, there are general tendencies. Corporate law seldom limits board discretion unless corporate actions or decisions share the following two characteristics: (1) 
mix of governance contracting ${ }^{133}$ and regulations.

Regulations would typically focus on either vertical side attempting to circumvent the other's fundamental rights. In terms of deal structuring, the court is very much pro-board. Hence, under the Delaware free market doctrine of independent legal significance, ${ }^{134}$ a board could choose an "asset sale" over a "merger," which potentially bypasses certain shareholder rights. ${ }^{135}$ On more fundamental governance matters, however, Schnell ${ }^{136}$ and Blasius $^{137}$ clearly prohibit managers from amending bylaws

they are large relative to the participants' stake in the company [and hence, I observe likely to constitute some degree of "investment" tinkering, versus strictly pursuing "strategic" objectives], and (2) they create a possible conflict of interest for directors, even if this conflict does not rise to the level of a self-dealing transaction."). Fundamental matters could include issues like charter and certain bylaws amendments, director elections, certain fundamental transaction deals (M\&A) and dissolution. Beyond voting, certain fundamental deals could trigger "statutory appraisal" rights for dissenting shareholders - or even fiduciary duties "plus," such as Revlon or Weinberger deal "maximization" duties owed to public shareholders.

133. See Del Code. Ann. Tit. 8 § 109(a) (typically "neutrally" giving each vertical side considerable "unilateral" bylaws amendments powers to expand one side's rights and limit the other's, subject to the charter); Del Code. Ann. Tit. $8 \S 109$ (a) (but the board cannot "unilaterally" undo shareholder adopted bylaws); Del Code. Ann. Tit. 8 § 141(a) (but extreme shareholder adopted "unilateral" bylaws might potentially undermine the board's centralized management powers); Del Code. Ann. Tit. $8 \S 242$ (b) (charter amendments, however, require "bilateral" support, making amendments of "governance" terms more difficult). But see Marco Ventoruzzo, Empowering Shareholders in Directors' Elections: A Revolution in the Making, 7 EUROPEAN COMP. FIN. L. REV. 105 (2010) (noting how historically management had the contractual upper hand with provisions like plurality director voting, but today the rise of institutional investor activism might make all this moot).

134. But see William J. Carney, The Mystery of Delaware Law's Continuing Success, 2009 U. ILL. L. REV. 1, 14 (observing how some see theorists see a "gradual erosion of the doctrine of independent legal significance....”).

135. See Hariton v. Arco Electronics, Inc., 41 Del. Ch. 74 (Del. Ch. 1963) (merger shareholder rights bypassed in an asset reorganization, notwithstanding similar results). But see Farris v. Glen Alden, 143 A.2d 25 (Pa. 1958) (some states adopt a more "paternalistic" regulatory view on the matter, known as the de facto merger doctrine).

136. See Schnell v. Chris-Craft Industries, Inc., 285 A.2d 437, 439-440 (Del. 1971) (describing how management amended the bylaws to move up the shareholders' annual meeting to stop an insurgent shareholder proxy fight to replace the incumbent board, but the court found that even legal bylaws amendments would be impermissible, in equity, since they were anti-democratic); William J. Carney, The Mystery of Delaware Law's Continuing Success, 2009 U. ILL. L. REV. 1, 13 (“After offering practitioners considerable clarity about their clients' freedom of action under Delaware law, the Delaware Supreme Court's equitable interests (implied in Judge Leahy's language in Langfelder), reasserted themselves in Schnell v. Chris-Craft Industries.").

137. See Blasius Industries, Inc. v. Atlas Corp., 564 A.2d 651 (Del. 1988) (describing how management amended the bylaws to increase the size of the board as a takeover defense against an insurgent shareholder proxy fight seeking board control, which was impermissible under Unocal scrutiny, since it was anti-democratic). 
antidemocratically. Inversely, although shareholders have broad fundamental governance powers, Hollinger ${ }^{138}$ prohibits a controlling shareholder from amending the bylaws, if abusive.

\section{b. Regulations}

One might first observe the philosophy of Delaware's vertical regulations. On the one hand, managers are $100 \%$ paid agents and without property in the corporation apart from the rise of incentive schemes. Hence, as pure agents, such managers at times might shirk, ultimately harming firm value. ${ }^{139}$ On the other hand, all managers have some form of corporate centralized management position rights and functions, which call for significant discretions, a reasonably necessary byproduct of large complex corporations that ultimately facilitates firm value.

Hence, to deter reckless agents, Delaware law first calls for fiduciary duty ideals. However, such duties can induce the opposite problem of overcautious and deterred agents. Hence, in quite a few cases, purely hortatory duties are effectively eliminated by a dominant business judgment rule presumption that frequently protects managers from corporate liabilities for breaches of certain fiduciary duties. ${ }^{140}$ "[M] ost jurisdictions recognize a . . principle of corporate law, the business judgment rule, which effectively insulates from legal challenge business decisions taken in good faith (that is, without intent to harm the company)." "141 In short, this shielding principle is very much a "let it be" sort of notion.

As a back-up, sometimes Delaware permits either indemnification ${ }^{142}$ (but not for "bad faith") ${ }^{143}$ or insurance payments (up to policy "limits"), ${ }^{144}$

138. See Hollinger International, Inc. v. Black, 844 A.2d 1022 (Del. Ch. 2004) (concluding that it was impermissible when a controlling shareholder sought to amend the bylaws to stop the board's poison pill takeover defensive powers that tried to shut down the controller's allegedly abusive sale, in violation of the spirit of duties and contract).

139. See Jonathan R. Macey \& Geoffrey P. Miller, An Economic Analysis of Conflict of Interest Regulation, 82 IowA L. REV. 965, 968 ("Every time one person (the agent) acts on behalf of another person (the principal), the agent has an incentive to shirk or serve his own interests, simply because the agent does not capture the full benefit of his labor.").

140. Anatomy, supra note $15, \S 3.6$ ("All managerial and board decisions are constrained by general fiduciary norms, such as the duties of loyalty and care."). The natures of care and loyalty duties are largely intuitive. One could imagine any boss wanting not only various forms of diligence from his employees, but also service with full loyalty.

141. Id. at $\$ 3.6 .1$.

142. See Del Code. Ann. Tit. $8 \S 145$ (a) (2018).

143. See Waltuch v. Conticommodity Services, 88 F.3d 87 (2d Cir. 1996) ("additional" indemnification powers do not encompass "bad faith").

144. See Del Code. Ann. Tit. $8 \S 145(\mathrm{~g})$ (2018). 
effectively creating a secondary business judgment rule "lite," but subject nonetheless to much worse reputational "breach" implications.

Beyond courts, I might additionally point out how, in the current environment, there are always market "super-regulations" at work. For example, from a stick perspective, inefficient or otherwise unpopular ${ }^{145}$ managers might incur institutional shareholder wrath, via the "coordinated" exercise of their property rights (like selling stock, voting out management or ISS issuing negative ratings). Moreover, beyond ISS, the market for corporate control always threatens to punish inefficient managers with an imminent "hostile" takeover. Beyond any form of stick, managers today can further be "super-regulated" through the rise of carrot incentive compensation schemes, ${ }^{146}$ re-directing their incentives more in the direction of shareholders. Thus, given all the above checks, a judicial decision to leave the matter to the free markets still will subject the managers to significant "de facto" regulations. Perhaps then the big question is what actual judicial "regulations" are still "necessary"?

\section{Duty of Care}

\section{Gross Negligence}

In the case of ordinary non-conflicted business decisions, the relevant fiduciary duty checking bad management decisions is the duty of care. Fraidin observes that "care" typically involves "informational and pure process factors." $" 147$

Philosophically, the idea of "care" is simply to produce a reasonably "diligent" decision, which seems a straightforward desire from the principal's perspective. But like all duties, "care" ideals give rise to a conundrum. On the one hand, without "care" ideals, managers as shirking agents might at times make very inattentive decisions (hence taking "reckless risks"), thus harming firm "value." On the other hand, the law mandating too much "care" would engender serious social problems, given the fact that many "strategic" decisions are complicated and highly ex ante indetermination, requiring risks of mistakes. Hence, too much "care" could

145. I have read articles about ISS being upset about "value" issues (particularly shortterm), such as unfair governance practices (say overly strong takeover "defenses") and not distributing sufficient dividends (especially in the absence of a terrific firm "long-term" plan) - and "ethics" issues, such as perceived poor CSR practices.

146. See supra Section II.E.

147. Samuel N. Fraidin, Duty of Care Jurisprudence: Comparing Judicial Intuition and Social Psychology Research, 38 U.C. DAVIS L. REV. 1, 22 (2004). 
lead to managerial risk aversion, ${ }^{148}$ thus also harming firm "value," in the big picture.

Drawing that fine line sounds like it could be quite difficult and elusive. But in a hard-working land with market checks like the United States, one would expect that, for the most part, regulations do not have to police "care" so strictly, hence here the Delaware law typically invokes a strong business judgment rule "shield," unless something is horribly wrong in a very obvious way. ${ }^{149}$ Fraidin observes that "care" typically involves "informational and pure process factors." 150

Hence, in normal non-conflicted decision-making, managers should simply be "reasonably" informed about the benefits of their decisions ${ }^{151}$ and have back-up evidence therefor (even if ultimately mistaken). Not having such a minimal basic "informational process" would obviously have zero "care utilities," even taking into account management's "strategic" role.

The first signal that the duty of care could be breached came in a management discredited era in the Aronson v. Lewis case (1984) ${ }^{152}$ which suggested that only something as severe as "gross negligence" would rebut the protective presumptions of the business judgment rule. ${ }^{153}$ Since there are powerful theoretical reasons for the business judgment rule "shield," the court was likely thinking that for strictly "care" problems, only something terrible would break it.

Then, one year later, Van Gorkom ${ }^{154}$ held managers liable under Aronson "gross negligence" principles. ${ }^{155}$ After Van Gorkom, vertical

148. See Gagliardi v. TriFood Inten., Inc. 683 A.2d 1049, 1053 (Del. Ch. 1996) ("Shareholders can diversify the risks of their corporate investments. Thus, it is in their economic interest for the corporation to accept in rank order all positive net present value investment projects available to the corporation, starting with the highest risk adjusted rate of return first. Shareholders don't want (or shouldn't rationally want) directors to be risk averse.").

149. "Indeed, before Van Gorkom, Delaware directors had never been held liable for a breach of the duty of care not also involving a breach of the duty of loyalty." Robert T. Miller, Smith v. Van Gorkom and the Kobayashi Maru: The Place of the Trans Union Case in the Development of Delaware Corporate Law, 9 WM. \& MARY Bus. L. REv. 65, 129 (2017).

150. Samuel N. Fraidin, Duty of Care Jurisprudence: Comparing Judicial Intuition and Social Psychology Research, 38 U.C. DAvis L. REV. 1, 22 (2004).

151. See Paramount Commc'ns, Inc. v. Time Inc., 571 A.2d 1140, 1150 (Del. 1989) (“[T]he question of 'long-term' versus 'short-term' values is largely irrelevant because directors, generally, are obliged to chart a course for a corporation which is in its best interests without regard to a fixed investment horizon.").

152. Aronson v. Lewis, 473 A.2d 805 (Del. 1984).

153. Id. at 812 ("[O]ur analysis satisfies us that under the business judgment rule director liability is predicated upon concepts of gross negligence.").

154. Smith v. Van Gorkom, 488 A.2d 858 (Del. 1985).

155. Id. at 880 ("The Court found those factors denoting competence to be outweighed by 
regulated entities were not sure whether all duty of care issues would be more heavily scrutinized from then on, while others believed that Van Gorkom was strictly a limited "takeover sale" case. "There is a basic question as to whether [Van Gorkom] is a duty of care case or a takeover case." 156

I observe that the facts of Van Gorkom involved an obvious "takeover sale" to a management favored white knight bidder who had a reputation for being very lovable to do business with. Moreover, apart from management's understandable "love" for its "favored," the board's deal also looked quite good by several relevant metrics.

By stock metrics, the board had some informational process to back up its sale decision, with both some form of front-end valuation study, combined with a back-end market test. ${ }^{157}$ Furthermore, the sale price appeared to give the existing shareholders a very hefty $44.7 \%$ premium above market price. By firm metrics, the corporation had tax problems that prohibited the firm from utilizing its tax credits and this favored sale was anticipated to unlock its slumbering value. ${ }^{158}$

But the problem is that this deal, while good, was non-maximized, since both the front-end and back-end had process problems or imperfections. While the back-end process requirements are largely determined by the subsequent Revlon doctrine jurisprudence, ${ }^{159}$ Van Gorkom articulated frontend ideals that still stand today. Before recommending the deal, management should have a "final" valuation study that values the company in all sale contexts ${ }^{160}$ and with regard to all key assets. ${ }^{161}$ Further, the board should have enough of an advance notice, and a long enough actual meeting time, to contemplate and reflect on that study, and then ask and discuss tough questions about it. ${ }^{162}$

evidence of gross negligence ....").

156. William T. Allen \& Reinier Kraakman, Judicial Protection: The Business Judgment Rule, in COMMENTARIES AND CASES ON THE LAW OF Business ORganizATIONS (TEACHER's MANUAL) (2016), § 6.4 [hereinafter Commentaries and Cases].

157. See id. at 878 (noting the defendants' reliance on the performance of a market test to eliminate the need for the Board to perform any other fairness test). By a market test, I mean some form of entertaining alternative bids to put the favored bid's supposed superiority to the test.

158. See id. at 864 ("[T] he Company had difficulty in generating sufficient taxable income to offset increasingly large investment tax credits.").

159. See infra Section IV at 55 (discussing the effects and triggers of the Revlon doctrine).

160. See Van Gorkom, 488 A.2d at 876 (observing how the board's study failed to value the firm in all contexts).

161. See id. (noting that the valuation study also did not consider key assets).

162. See id. at 875 ("Considering all of the surrounding circumstances — hastily calling the meeting without prior notice of its subject matter, the proposed sale of the Company without any prior consideration of the issue or necessity therefor, the urgent time constraints 
Unlike in classic strategic decision situations that are largely indeterminate ex ante, the court felt like the "takeover sale" process was obvious, or strictly a matter of common sense, essentially being nothing more than a reasonable front-end plus back-end process. In this special context, under auction theory, the right process should always yield a maximized deal result, hence in theory less process would have absolutely zero utilities for the society. With management discredited in the 1980s, the court made a trumpet call for a better process in obvious situations, thereby hopefully curbing reckless managerial risk-taking, where it was reasonably possible to do so. Hence, Van Gorkom "care" at last hoisted over the business judgment rule "shield" arguably represented a very extreme set of facts.

\section{Charter Exculpations}

But was management in Van Gorkom actually so terrible, if they produced a quite good deal by both agency and firm metrics? While the simple truth of an auction process in a "sale" is very likely justifiable, based on common sense, the court's trumpet call for more careful scrutiny nonetheless scared managers, who may have been thinking about a slippery slope eventually leading to the court second-guessing "strategic" decisions, and not only "takeover sales." All this could well have created the unwanted problem of over-deterring management (and consequently Delaware charter "law," given the threat of exodus). ${ }^{163}$ The legislature thus quickly acted and gave a Middle Way compromise solution, ${ }^{164}$ by making the Van Gorkom strictly "director" duty of care liability a "big boy" charter governance matter with DGCL, $\S 102(b)(7)^{165}$ charter exculpations. This provision permits, with

imposed by Pritzker, and the total absence of any documentation whatsoever - the directors were duty bound to make reasonable inquiry of Van Gorkom and Romans, and if they had done so, the inadequacy of that upon which they now claim to have relied would have been apparent."). But it is also worth noting that some theorists would argue that in a more "exigent" emergency situation not of management's own creation, then management should be able to act with "less process" and still meet its "care" duties. Bill Carney once proposed to me the problem of the board receiving a "whopper" bid with an "urgent" deadline, not of the board's own creation.

163. See Nees supra note 25, at 210 ("Van Gorkom triggered a backlash in corporate law over the fear that it would chill the American entrepreneurial spirit within the boardroom.").

164. See Matthew R. Berry, Does Delaware's Section 102(b)(7) Protect Reckless Directors from Personal Liability? Only if Delaware Courts Act in Good Faith, 79 WASH. L. REV. 1125, 1137 (2004) (“After Van Gorkom, the Delaware legislature responded to directors' fears of potential liability and shareholders' desire to retain quality, risk-taking directors by enacting section 102(b)(7).”).

165. Del Code. Ann. Tit. $8 \S 102(\mathrm{~b})(7)$ (providing that the charter can eliminate or limit 
"bilateral" approval (board and shareholders), blanket exculpation of all vertical strictly "care" duties problems, ${ }^{166}$ without the need for case-by-case outsider ratification. ${ }^{167}$ All this, by contract, effectively enlarges the board's business judgment rule "shield."

Today, the vast majority of public corporations take this charter exculpation tactic, ${ }^{168}$ hence "opting out" of Van Gorkom is far and away the norm, notwithstanding its technical continued existence as "default" law. All this is probably for the best, since if there are equally strong arguments on both sides, Middle Way makes sense. Further, with the rise of institutional investors, "contractual" ratification becomes more and more meaningful.

\section{Duty of Loyalty}

\section{Entire Fairness}

Disloyalty is the far more complicated (and potentially more intrusive) of the two major Delaware fiduciary duties. One must first philosophically assess what exactly is disloyalty. On the one hand, at some degree too much self-interest clearly impairs insider "objectivity" and becomes agency "abusive." Hence, at least certain conflicts must be scrutinized with some degree of "reasonable skepticism." On the other hand, corporate directors are obviously not pure fiduciary machines. Some degree of self-interest is omnipresent, ${ }^{169}$ natural and healthy ${ }^{170}$ for human beings. Hence, given the bad and good together, the law must not "over-police" conflicts, but instead

"the personal liability of a director to the corporation or its stockholders. ...", subject to certain carve-outs).

166. See Berry, supra note 164, at 1138 ("Delaware courts interpret section 102(b)(7) to protect directors from personal liability arising from all duty of due care violations.").

167. I observe that, in contrast to disloyalty problems, there is typically no need for "outsider" ratification of straight care issues, since care is inherently an "insider" issue. Insiders are best poised to assess their strategic calculations, absent taint.

168. See Bernard S. Sharfman, The Enduring Legacy of Smith v. Van Gorkom, 33 DEL. J. CORP. L. 287, 289 (2008) ("Professor Hamermesh reported that out of a sample of one hundred Fortune 500 companies, ninety-eight had adopted an exculpatory provision.").

169. Life obviously involves "potentially" conflicting interests in nearly every situation. Even a friend today could become a rival tomorrow. Or, in business, a lucratively salaried CEO would obviously want the company to do well, but then could become too selfish when negotiating for his or her own compensation.

170. I observe a few possible good outcomes for certain conflicted interest deals. Dealing with arm's length strangers (while very clean) involves a lot of uncertainty, so there are at times advantages to insiders dealing with people that they know and trust (such as themselves), with potentially lower negotiation and transaction costs. Also, if insiders can extract some extra money out of the corporation, then perhaps they could also work for less corporate money, achieving some form of "scale" cost reductions. 
simply re-right the ship.

A bit amorphous, the court has noted the "classic sense" of disloyalty, as "preferring the adverse self-interest of the fiduciary or of a related person to the interest of the corporation. ..."171 I observe how vertical disloyalty could then be viewed simply as a vertical freeze-out, or "over-reaching," i.e., the managers seizing "too much," without a sufficiently even enough "quid pro quo," to the exclusion and detriment of the public shareholders. ${ }^{172}$

When tracing out the Delaware law of disloyalty, the first step is to ask if there is a loyalty duty, "to whom" exactly is that duty owed? In the early days, boards had to be $100 \%$ obedient to the "short-term" interests of their shareholders. ${ }^{173}$ Whereas in Delaware, today, boards have flexibility to discharge their duties to help virtually any corporate constituency, if for the overall good of the "firm," ${ }^{174}$ unless in Revlon mode, which only then would require strictly the old Dodge "short-term" shareholder obedience.

Disloyalty also comes in a couple flavors, one milder and the other more pungent. In Delaware, soft forms of managerial disloyalty are often not viewed with great regulatory suspicions, like say parachutes ${ }^{175}$ law $^{176}$ or even Unocal "takeover" defenses (discussed below). Both of these, while raising some modicum of obvious taint alarm, both can be very good things as well, by either aligning "takeover" interests or fighting off raider "threats."

The more interesting topic is hard disloyalty, i.e., situations where insider conflicts more obviously flare up, which could broadly encompass a multitude of potentially "abusive" conflicted areas, such as managerial compensation, managers on both sides of a transaction, even other subtler conflicts of interest (such as say in Cooke, where self-interested directors allegedly sought to protect their interests as creditors rather than pursue

171. In re Walt Disney Co. Derivative Litigation, 906 A.2d 27, 66 (Del. 2006).

172. See infra note 303 and accompanying text (horizontal freeze-out standard).

173. See Dodge v. Ford Motor Co., 204 Mich. 459 (Mich. 1919) (no flexibility to use corporate funds to pursue "long-term" purposes).

174. See Unocal v. Mesa, 493 A.2d 946 (Del. 1985) (flexibility for boards to pursue "longterm" interests, if "rationally related" to shareholder value).

175. See Henry F. Johnson, Those "Golden Parachute" Agreements: The Taxman Cuts the Ripcord, 10 DEL. J. CORP. L. 45, $46-48$ (1985) (noting the increase in parachutes, which insure against job loss, as a compensation mechanism for managers involved in hostile takeovers).

176. For example, the Sixth Circuit Campbell court, applying Delaware law, held that parachutes would receive summary judgment for the defendants on the business judgment rule issue. See Campbell v. Potash Corp. of Saskatchewan, Inc., 238 F.3d 792, 800 (2001) ("In short, evaluating the costs and benefits of golden parachutes is quintessentially a job for corporate boards, and not for federal courts."). 
superior shareholder value), ${ }^{177}$ or the highly amorphous corporate opportunity doctrine. ${ }^{178}$ All of these situations raise sharper alarm that the firm might be hurt by the insider's self-interest. Hence, the Delaware law machinery then comes into greater play.

The first major mention of Delaware vertical disloyalty liability came in the management discredited post-Depression era (1939) in Guth v. Loft, ${ }^{179}$ which held that hard enough vertical disloyalty would result in a "constructive trust" immediately disgorging all profits. ${ }^{180}$ This meant that impermissible vertical disloyalty was $100 \%$ void, without further "fairness" scrutiny. Philosophically, that meant that the law asked agents to be perfect fiduciary machines, which was obviously unfair for managers, if what they did was ultimately "fair" and good for the corporation. Hence, in the subsequent more prosperous American post-war years restoring management credibility, Gottlieb v. Heyden Chemical Corp. ${ }^{181}$ shifted the $100 \%$ void disloyalty rule to the vertical freeze-out standards of "inherent fairness," meaning that the insider could potentially prove that any tainted deal was ultimately "fair," "182 especially after full disclosures. ${ }^{183}$ The

177. Cooke v. Oolie, 2000 WL 710199 at*1 (Del. Ch. 2000).

178. Sometimes insider fiduciaries seek to pursue "personal" opportunities, which to the fiduciaries are "outside" their fiduciary capacities, but which to the corporation should arguably nonetheless "belong to" the corporation. The argument that directors are not fiduciary machines has even stronger potency when their "personal" lives implicate matters that seem arguably "outside" the corporation, and hence "reasonably necessary" parts of existence, just like say care "discretion." But some might fear too many insider "abuses." Different societies use a number of "test-paradigm" variations, which could look at both "the means" and "ends" of the disputed "opportunities," all attempting to draw the ambiguous line between what "opportunities" are fundamentally "inside" versus "outside." Just like the "testparadigm," the "factual" resolutions under any adopted test could be equally ambiguous, following this riddle.

179. Guth v. Loft, 23 Del. Ch. 255 (Del. Ch. 1939).

180. See id. at 270 ("Given the relation between the parties, a certain result follows; and a constructive trust is the remedial device through which precedence of self is compelled to give way to the stern demands of loyalty.").

181. 33 Del. Ch. 82 (Del. Ch. 1952).

182. See id. ("In such a situation the burden is upon the directors to prove not only that the transaction was in good faith, but also that its intrinsic fairness will withstand the most searching and objective analysis.").

183. In the old days, lack of disclosures rendered a "conflicted" as $100 \%$ "void," probably recognizing the paramount importance of keeping shareholders alerted about possible "abuses." Such an approach might have derived from partnership law's fine "fiduciary" duties under Meinhard v. Salmon. Today, lack of "disclosures" might simply play into Weinberger "entire fairness", probably recognizing that a "fair deal" results in no prejudice to the shareholders. However, even in the current day, absolute horrors like "fraud" are at times treated as $100 \%$ void, although Weinberger suggested possible "equitable remedies" instead. The line between "conflicts" and "fraud" is perhaps not always so clear, but presumably 
Weinberger case ${ }^{184}$ added that any "entire fairness" scrutiny would involve two aspects, "fair dealing" plus "fair price.", 185

\section{Takeover Jurisprudence}

The centerpiece issue in vertical takeover decisions is that of takeover defenses. It is worth first defining what one means by defenses. Scholars have talked about managers' powers to "just say no" to hostile bidders, ${ }^{186}$ since an effective "defense" almost guarantees that "outsider" bidders will be unwilling to purchase shares directly from shareholders, unless and until redeemed. I add that it could also be defined as managers' powers zealously to pursue their favored and disfavor their unwanted alternatives, which I refer to as their "love and hate" powers.

As noted, while takeovers are good and bad, ${ }^{187}$ so are management's defenses. While defenses can protect the corporation, perhaps because managers think more "long-term" than "confused" shareholders, ${ }^{188}$ managers can also act self-interestedly out of entrenchment desires, fearing being fired by a hostile bidder, ${ }^{189}$ and defenses in some cases can even eradicate significant portions of the shareholders" "investment." 190

Hence, Delaware law has evolved to be very complex minded on the question of defensive disloyalty. The takeover disloyalty analysis is essentially split between two distinct doctrines, which Kraakman refers to as two different acts, ${ }^{191}$ with first Unocal ${ }^{192}$ on the one hand, versus the later

"fraud" would encompass both clearer lying and stealing as well as a "scienter" level of culpability.

184. Weinberger v. UOP, Inc., 457 A.2d 701 (Del. 1983).

185. I add that the subsequent Trados case clarified that "unfair dealing" alone would not flunk "fairness" review, to the extent it didn't infect "price." See In re Trados Inc. Shareholder Litigation, 73 A.3d 17 (Del. Ch. 2013) ("Under the circumstances of this case, the fact that the directors did not follow a fair process does not constitute a separate breach of duty. As the Delaware Supreme Court has recognized, an unfair process can infect the price, result in a finding of breach, and warrant a potential remedy.").

186. See Marcel Kahan \& Edward B. Rock, How I Learned to Stop Worrying and Love the Pill: Adaptive Responses to Takeover Law, 69 U. CH. L. REV. 871, 872 (2002) (asking whether poison pill legality meant that "managers could 'just say no."').

187. See supra Section II.

188. See infra Section IV.

189. Shane M. Shelley, Entrenched Managers \& Corporate Social Responsibility, 111 Penn St. L. Rev. 107, 113 (2006) ("For example, Professors Bebchuk, Cohen and Ferrell argue... two takeover defenses particularly entrench managers from shareholder and takeover accountability and, in the end, are strongly associated with lower financial value.").

190. See infra Section IV.

191. See Commentaries and Cases, supra note 156, $\S 12.1$.

192. See Unocal v. Mesa Petroleum Co., 493 A.2d 946, 958 (Del. 1985) (discussing "non- 
Revlon ${ }^{193}$ on the other. As will be shown, the Unocal typically pro-board defensive powers are balanced out with the Revlon pro-shareholder auctioneering duties. Like day and night, Unocal and Revlon modes can never be invoked at the exact same moment (one always withdraws from the other), ${ }^{194}$ though I observe some twilight, with cases such as Time, Ivanhoe, Restaurant Associates and even Omnicare, ${ }^{195}$ all of which are viewed by the court as Unocal rather than Revlon cases.

\section{i. Unocal (Act I)}

Leading up to Unocal, in the post-war management credibility era of the 1960s, the board had wide "unilateral" takeover defensive powers, under Cheff. ${ }^{196}$ "[D]irectors satisfy their [defensive] burden by showing good faith and reasonable investigation; the directors will not be penalized for an honest mistake of judgment ...."

But in the complex 1980s years, the Unocal court needed to rethink its takeover defense jurisprudence. After embracing Cheff as its first prong, Unocal adopted the novel intrusive-sounding proportionality standard for evaluating the board's takeover defenses, meaning that any "unilateral" defenses must be "reasonable in relation to the threat posed." 198 That standard is known as a form of intermediate scrutiny, somewhere between the business judgment rule and entire fairness in terms of court intrusiveness. ${ }^{199}$ I might observe that the vertical conflicts duties are perhaps

takeover sale" defenses).

193. Revlon, Inc. v. MacAndrews \& Forbes Holdings, Inc., 506 A.2d 173, 185 (Del. 1986) (discussing "takeover sale" defenses).

194. Plato, Phaedo, in Plato: Collected Dialogues 84, 84 (Edith Hamilton ed. 1999) ("It seems to me not only that the form of tallness itself absolutely declines to be short as well as tall, but also that the tallness which is us never admits smallness and declines to be surpassed.").

195. See infra Section IV at 66.

196. Cheff v. Mathes, 41 Del. Ch. 494, 508 (Del. 1964) (holding that "if the actions were proper because of a decision by the board made in good faith that the corporate interest was served thereby, they are not rendered improper by the fact that some individual directors were willing to advance personal funds if the corporation did not.").

197. Id. at 506.

198. See Unocal v. Mesa Petroleum Co., 493 A.2d 946, 955 (Del. 1985) ("If a defensive measure is to come within the ambit of the business judgment rule, it must be reasonable in relation to the threat posed."). As a subsequent case makes clear, "bilateral" charter amendments "defenses" typically aren't subject to Unocal - but could conceivably violate "public policy" limits. See, e.g., Williams v. Geier, 671 A.2d 1368 (Del. 1996).

199. See Richard E. Kihlstrom \& Michael L. Wachter, Corporate Policy and the Coherence of Delaware Takeover Law, 152 U. PA. L. REv. 523, 529 n.19 ("In Unocal, the court favored intermediate scrutiny."). 
reduced here, since Unocal is not a pure vertical axis issue, but additionally implicates "external" axis questions with arguably "outsider" raiders.

Today, the starting point of the Unocal analysis is dealing with a corporate "threat," which has both a qualitative and quantitative dimension. ${ }^{200}$

Qualitatively, Unocal mentioned a laundry list of such threats:

Examples of such concerns may include: inadequacy of the price offered, nature and timing of the offer, questions of illegality, the impact on 'constituencies' other than shareholders (i.e., creditors, customers, employees, and perhaps even the community generally), the risk of nonconsummation, and the quality of securities being offered in the exchange. ${ }^{201}$

However, quantitatively speaking, a Unocal "threat" potentially justifying proportional defenses is not a none-or-all thing, but a question of degree. Merely mild threats will justify fewer defensive powers. ${ }^{202}$

In any event, the actual Unocal case "threat analysis" was mostly worried about short-term value inadequacy, with the hostile bidder seeking to do some form of low-ball "outright" coercive two-tier bid. ${ }^{203}$ The later Time $^{204}$ case confirmed that a Unocal inadequate bid "threat" could also include a threat to the corporation's long-term value, even if the hostile bid was at an apparently whopper price by short-term value metrics. ${ }^{205}$ Further, the Time court even held that protecting a "value" corporate "culture"206

200. See Unocal, 493 A.2d at 955 (finding that a defensive measure "must be reasonable in relation to the threat posed").

201. Id.

202. Chesapeake Corp. v. Shore, 771 A.2d 293 (Del. Ch. 2000) (finding a mild Unocal inadequate bid threat, and consequently less managerial defensive justifications); see, e.g., Unitrin, Inc. v. American General Corp., 651 A.2d 1361, 1389 (Del. 1995) ("[A]s a defensive response... it was limited and corresponded in degree or magnitude to the degree or magnitude of the threat, (i.e., assuming the threat was relatively 'mild,' was the response relatively 'mild?')").

203. See Unocal, 493 A.2d at 956 ("Specifically, the Unocal directors had concluded that the value of Unocal was substantially above the $\$ 54$ per share offered in cash at the front end. Furthermore, they determined that the subordinated securities to be exchanged in Mesa's announced squeeze out of the remaining shareholders in the 'back-end' merger were 'junk bonds' worth far less than $\$ 54 . ")$.

204. Paramount Communications, Inc. v. Time Inc., 571 A.2d 1140 (Del. 1989).

205. See id. at 1147 ("On June 7, 1989, these wishful assumptions were shattered by Paramount's surprising announcement of its all-cash offer to purchase all outstanding shares of Time for $\$ 175$ per share. The following day, June 8, the trading price of Time's stock rose from $\$ 126$ to $\$ 170$ per share.").

206. Time Inc., 571 A.2d at 1152 (noting that the board protected its perceived journalistic integrity "culture"). 
could be a Unocal threat. ${ }^{207}$

Kraakman calls these novel Time long-term Unocal "threats" as "substantive coercion," 208 a subtler form of coercion than "outright" two-tier bids, essentially meaning that confused shareholders with short-term bias ${ }^{209}$ will ignorantly pick short-term over the superior long-term benefits of management's favored strategic plan. ${ }^{210}$

While the Delaware courts likely had the right idea with a Unocal intermediate scrutiny standard, given the good and bad of takeovers and all involved, the details were not fully worked out. Unocal resulted in upholding an anti-democratic takeover defense that coerced the corporation's own shareholders. By stock metrics, shareholders, who refused to tender into the board's repurchase defense, would likely be diluted, given the whopper repurchase price and the probability of the alternative defeated hostile bid falling through. Moreover, shareholders who did tender ended up with " $\$ 1.1$ billion less than shareholders would have received had [the hostile bid] been successful...."211 Further, by firm metrics, the board's repurchase defensive measures were a form of scorched earth, paying out to the tendering shareholders too much capital, which later left the corporation itself in dire straits. ${ }^{212}$

Sociologically speaking, in this complex "takeover" era, perhaps the court was under too much pressure to deal with the rampant Hollywood

207. But see eBay Domestic Holdings, Inc. v. Newmark, 16 A.3d 1, 33 (Del. Ch. 2010) (finding that providing free on-line classified advertisements to the community was not evidence that corporation possessed "a palpable, distinctive, and advantageous culture that sufficiently promoted stockholder value ....").

208. I view this as the mother of all Unocal "threats." However, in a PLI conference, I heard it said that Vice Chancellor Laster was contemplating backtracking on the existence of the "substantive coercion" threat, as shareholders become more institutional, who perhaps should not be as confused, if fully informed? The answer to this debate possibly depends on whether institutional shareholder musculature helps them understand long-term value, or whether it is strictly a short-term value deal competence virtue.

209. See Grant Hayden \& Matthew T. Bodie, Shareholder Democracy and the Curious Turn Toward Board Primacy, 51 WM. \& MARY L. REV. 2071, 2092 (2010) (“Another set of theorists ... base their analyses not on a model of corporate structure, but rather on concerns about the influence of short-term interests. In their view, shareholders have developed an extremely short time horizon by which they judge the success of the corporation and its leadership. As boards and officers have come under more pressure to follow the desires of shareholders, they have adopted the goal of short-term share price maximization. This focus, they argue, has skewed the perspectives of shareholders and, as a result, has hurt the longterm efficiency of corporations.").

210. See Commentaries and Cases, supra note 156, $\S 12.2$ ("The idea that shareholders might tender out of ignorance or mistaken belief about the value of their stock.").

211. Carney, supra note 46, at 329.

212. See id. ("Unocal paid out $59 \%$ of its pre-takeover bid equity to shareholders in this restructuring.”). 
problems and protect the "independent" bedrock of Delaware corporate democracy. In any event, after not quite finding its "balanced" footing, the court then had to set off on an adventure to find the right Unocal proshareholder "limits" on board powers.

The subsequent Time case shows that today, courts still have great tolerance for a poorly decided takeover defense decision, which can be chalked up to managerial "strategic" powers. ${ }^{213}$ For the court, antidemocracy was and always is a bigger problem than poor decisions. As will be shown, Delaware courts now have minimal tolerance for shareholder proxy fight interference, zero tolerance for coercion, and perhaps a bit more latitude for preclusion.

A few subsequent shareholder democracy cases are worth mentioning. First, Blasius Industries, Inc. v. Atlas Corp. ${ }^{214}$ held that management could no longer take Unocal "reactive" defensive measures, once an insurgent shareholder signaled any form of proxy fight or consent solicitation on the horizon, at least not without meeting the heavy burden of a "compelling justification.",215 Interestingly enough, management in Blasius was protecting what appeared to be a very intelligent plan in the face of a poorly decided insurgent plan that was too highly leveraged, but the "compelling justification" question is never smart or poorly decided, but democratic or undemocratic. $^{216}$ As Blasius states, "The theory of our corporation law

213. See Paramount Communications, Inc. v. Time Inc., 571 A.2d 1140, 1147-1148 (Del. 1989) (describing the circumstances under which the board turned down a "whopper" hostile bid for its own long-term strategic plan that created desperate indebtedness for the corporation).

214. 564 A.2d 651 (Del. 1988).

215. See id. at 661 (holding that the board must demonstrate a compelling justification for acts that impede the exercise of shareholder voting power). Some later Blasius-line cases point out that, in such situations, management is not even permitted to weaken the insurgent, short of $100 \%$ foreclosing the insurgent. See, e.g., MM Companies, Inc. v. Liquid Audio, Inc., 813 A.2d 1118 (Del. 2003) (holding that management could not even partially "dilute" the influence of insurgent directors). Further, apart from Blasius, the Delaware court is likely to interpret the ambiguities of any proxy fight interfering bylaws provisions against the drafter. See, e.g., Jana Master Fund, LTD v. CNET Networks, Inc., 954 A.2d 335 (Del. Ch. 2008) (holding that CNET's advance notice bylaw applied only to shareholder proposals that are sought to be included in the company's proxy materials pursuant to Rule $14 \mathrm{a}-8$ under the Securities and Exchange Act of 1934, as amended, and therefore did not apply to independently financed shareholder proxy solicitations); Levitt Corp. v. Office Depot, Inc., 2008 WL 1724244 (Del. Ch. 2008); DiEleuterio v. Cavaliers of Del., Inc., 1997 WL 6338 (Del. Ch. 1987).

216. I might note that in the Time case, the opposite happened, where management made a poorly decided decision, which was both informed and democratic, and thus upheld. See Paramount Comm., Inc. v. Time, Inc., 1989 WL 79880 at *750 (Del. Ch. 1989) ("In the decision they have reached here, the Time board may be proven in time to have been brilliantly prescient or dismayingly wrong. . . That many, presumably most, shareholders 
confers power upon directors as the agents of the shareholders; it does not create Platonic masters." 217 Hence, when stressed so heavily in an active democratic proxy fight, the managerial corporate immune system must somewhat relax itself (interestingly the opposite functionality here of a human's immune system).

Second, Unitrin $^{218}$ held that under no circumstances could Unocal defensive measures ever become what the court called "coercive" or "preclusive." "219 "Coercive" was not defined by the court, but I read it as management making the shareholders some form of offer that they cannot refuse, like in the actual Unocal case. Unlike in Unocal, the repurchase in Unitrin was a free-will offer, ${ }^{220}$ since it was non-diluting at market prices as well as non-discriminatory. Hence, were Unitrin shareholders to have refused the board's repurchase, they would no longer be punished with value dilution like in the actual Unocal case.

For Unitrin "preclusion," the key question is whether the hostile bid "would either be mathematically impossible or realistically unattainable,"221 a heavy burden for a plaintiff. The assessment of mathematical possibility or impossibility is a complex inquiry, largely essentially determined by any number of empirical considerations relevant thereto, like takeover defensive trigger percentages (limiting ownership needed to run a successful proxy fight), ${ }^{222}$ majority versus plurality voting, the presence of a lot of institutional shareholders (known to oppose management), ${ }^{223}$ and even the board's

would prefer the board to do otherwise than it has done does not. . . afford a basis to interfere with the effectuation of the board's business judgment.").

217. Blasius, 564 A.2d at 663.

218. Unitrin, Inc. v. Am. General Corp., 651 A.2d 1361, 1389 (Del. 1995).

219. See id. at 1387-88 ("If a defensive measure is not draconian, however, because it is not either coercive or preclusive, the Unocal proportionality test requires the focus of enhanced judicial scrutiny to shift to "the range of reasonableness."').

220. See id. at 1388 ("Here, there is no showing on this record that the Repurchase Program was coercive.").

221. Id. at 1389. The dead hand pill cases also teach that poison pill defenses should not disable the power of future boards to redeem pills, in whole or in part, which obviously would obviously interfere with any insurgent shareholder proxy fights. See, e.g., Carmody v. Toll Brothers, Inc., 723 A.2d 1180 (Del. Ch. 1998) (prohibiting dead hand pills); Quickturn Design Sys., Inc. v. Shapiro, 721 A.2d 1281 (Del. 1998) (prohibiting even more moderated "slow hand" pills).

222. See Unitrin, 651 A.2d at 1382 ("If American General were to initiate a proxy contest before acquiring $15 \%$ of Unitrin's stock, it would need to amass only $45.1 \%$ of the votes assuming a $90 \%$ voter turnout.").

223. See id. at 1383 ("The record reflects that institutional investors held $42 \%$ of Unitrin's stock and 20 institutions held $33 \%$ of the stock. Thus, American General's own assumptions and calculations in the record support the Unitrin Board's argument that 'it is hard to imagine a company more readily susceptible to a proxy contest concerning a pure issue of dollars."'). 
significant ownership of stock (aligning interests). ${ }^{224}$ It is possible that, in certain special cases, if the board's "defenses" do keep the firm "independent" (and democratic), then the court might have a higher "preclusion" tolerance. 25

One last Unocal question is that of multiple cumulative defenses, meaning management stacking multiple defensive measures, one on top of the other. Unitrin held that multiple cumulative defenses could potentially be viewed as Unocal proportional. ${ }^{226}$ However, the later Chesapeake case suggests that, at least at times, multiple cumulative defenses might make the Unocal "threat" milder, in turn justifying fewer board defensive measures. ${ }^{227}$

Notice how as Unocal expanded vertical fiduciary duties, the pro-board subsequent developments of the doctrine effectively also proportionately expanded the board's business judgement rule "shield."

\section{ii. Revlon (Act II)}

Shortly after Unocal, the Revlon ${ }^{228}$ case came down, which potentially intensified the pro-shareholder duty of loyalty, ${ }^{229}$ in the event of an amorphous trigger of a "break-up."230 Below, I discuss the two key aspects of the Revlon doctrine, first effects and then triggers.

$\square$ Revlon Effects

Should Revlon be triggered, "[t]he directors' role change[s] from defenders of the corporate bastion to auctioneers charged with getting the

224. See id. ("Harold Hook, the Chairman of American General, admitted in his deposition that the repurchase program is not a 'show stopper' because the directors that own stock will act in their own best interest if the price is high enough.").

225. See Ivanhoe Partners v. Newmont Min. Corp., 535 A.2d 1334 (Del. 1987) (a 49.7\% white knight "defense" that kept the firm "independent." subject to a strong enough standstill agreement, did not breach Unocal, even though any future "takeover" would be improbable).

226. See Unitrin, 651 A.2d. at 1389 ("The Court of Chancery's holding in Shamrock, cited with approval by this Court in Time, appears to be persuasive support for the proportionality of the multiple defenses Unitrin's Board adopted.").

227. See Chesapeake Corp. v. Shore, 771 A.2d 293, 343 (Del Ch. 2000) ("The more important proportionality problem is the fact that the Supermajority Bylaw is an extremely aggressive and overreaching response to a very mild threat. The board already had a poison pill in place that gave it breathing room and precluded the Tender Offer.").

228. Revlon, Inc. v. MacAndrews \& Forbes Holdings, Inc., 506 A.2d 173, 173 (Del. 1986).

229. See id. at 182 ("The noteholders required no further protection, and when the Revlon board entered into an auction-ending lock-up agreement with Forstmann on the basis of impermissible considerations at the expense of the shareholders, the directors breached their primary duty of loyalty.").

230. See id. ("However, when Pantry Pride increased its offer to $\$ 50$ per share, and then to $\$ 53$, it became apparent to all that the break-up of the company was inevitable."). 
best price for the stockholders at a sale of the company." ${ }^{231}$ Hence, in Revlon mode, just like a common sense regular auction, a manager loses all forms of its Unocal "love and hate" defensive powers in favor of cosmic "detachment."

Beyond "price" alone, Dollar ${ }^{232}$ adds that Revlon can procure virtually any form of reasonable short-term shareholder value. Presumably, that could include deal terms, ${ }^{233}$ deal certainty, ${ }^{234}$ perhaps also deal quickness, ${ }^{235}$ but probably not more long-term things like deal synergies or strategies. ${ }^{236}$ Beyond the aforementioned, any varieties of "benefits" that a "final" shareholder can immediately realize should likely be viewed as Revlon "short-term value" (like say perhaps "deal" tax-advantaged structures).

The key to Revlon maximization evidence is a reasonably fair process. Barkan $^{237}$ and later Lyondell $^{238}$ teach that maximization evidence will ideally require some form of both reasonable front-end and back-end process. The centerpiece of that Revlon process lies in the back-end jurisprudence of defensive "lock-ups" (or favoritism).

In Revlon, the story began with a "hostile" bidder who came out likely "low balling," hence probably triggering management's dislike, which to management seemed obviously justifiable, the twin situation of management's favoritism for its likeable white knight in Van Gorkom.

231. Id. at 182 .

232. See Dollar, 13 A.3d at 595-96 ("[A]lthough the level of judicial scrutiny under Revlon is more exacting than the deferential rationality standard applicable to run-of-the-mill decisions governed by the business judgment rule, at bottom Revlon is a test of reasonableness; directors are generally free to select the path to value maximization, so long as they choose a reasonable route to get there.").

233. See id. at 576 ("Dollar Thrifty shut down talks in order to extract better terms. ...").

234. See id. at 616 ("As things now stand, what is standing between the stockholders and a deal with Avis is the Board's determination that it will not consider Avis to have made a superior proposal unless it provides a greater promise of closing certainty."). In Dollar, the board's favored deal was superior in terms of deal certainty from an antitrust and financing perspective. The favored deal also would give the company a reverse termination fee, as compensation if the deal fell through.

235. Bill Carney once pointed out to me how a corporation once had two interested bidders, one who was still preoccupied with another acquisition and a second who was haggling over executing a confidentiality agreement. Both slow bidders were reasonably excluded, for fear of a protracted process losing the first bidder, thus ultimately harming the process. One possibility here would be to ask fair a "fair opportunity" final bid to speed up all bidders, without any unreasonable exclusions.

236. See QVC, 637 A.2d at 34 (rejecting long-term value pursuits in Revlon mode).

237. Barkan v. Amsted Indus., Inc., 567 A.2d 1279 (Del. 1989).

238. See Lyondell Chem. Co. v. Ryan, 970 A.2d 235, 243 (Del. 2009) ("[D]irectors must 'engage actively in the sale process,' and they must confirm that they have obtained the best available price either by conducting an auction, by conducting a market check, or by demonstrating 'an impeccable knowledge of the market."'). 
Hence, management adopted much "excessive" favoritism to fight off an "unwanted" bidder alternative.

In the Revlon mode sale context, in contrast to Unocal, the court views any form of defensive "excessive" contractual, ${ }^{239}$ economics ${ }^{240}$ or governance $^{241}$ defensive lock-ups ${ }^{242}$ as disloyal favoritism, interfering with the reasonable openness of the back-end process, while strictly "moderate" favoritism is consistent with such process. I observe that when favoritism is kept only "moderate," the natural forces of the free markets should bring a reasonable number of interested bidders into the auction process, thus by necessity, under auction theory, a reasonably fair process should exist.

Kraakman points out how the Revlon prohibition of "excessive" favoritism was criticized as too pro-shareholder. The famous pro-board lawyer Martin Lipton observed how Revlon's prohibition thereof would potentially shut down the auction process, by keeping away subsequent bidders (fearing being a "stalking horse"). ${ }^{243}$ However, Lipton's rival proshareholder lawyer, Joseph Flom, took the opposite view and saw Revlon as the right precedent, believing that keeping some reasonable process open to the bitter end would maintain the reasonable openness of the auction process, ${ }^{244}$ ultimately maximizing shareholder short-term value.

239. Contractual lock-ups could include either no-shop or no-talk clauses. No-shop clauses prohibit active solicitation of subsequent other bidders, while more extreme no-talk clauses permit talking to them, even on an unsolicited basis.

240. Economics lock-ups could include lock-up options on shares or crown-jewel assets like in the Van Gorkom and Revlon cases. More moderated economics lock-ups would include reasonable termination fees. Any subsequent other bidder who acquires the company will have to pay out the company's economics lock-ups, thus deterring that bidder.

241. Governance lock-ups could include nixing a board's fiduciary out to pull a deal for a subsequent other bidder, or even shareholder voting commitments that cannot be pulled, all like in the Omnicare case.

242. While lock-ups have these three flavors, the idea of any favoritism lock-up given to a favored white knight better is simply to deter subsequent other bidders, thus making the first deal consummation more probable.

243. Commentaries and Cases, supra note 156, at $\S 12.4$ ("This is exactly the applepicking problem that we've been talking about: Forstmann finds an apple, and then he's got to compete with Perelman for the right to pick the apple. Well what kind of incentive is that to find the apple in the first place?"). Hence, Lipton observed: "The ability to bring somebody into a situation is far more important than the extra dollar a share at the back end. In other words, at the front end you're probably talking about $50 \%$. At the back end you're talking about one or two percent. By saying that you have to be open to the last dollar at the back end, maybe you'd better not start on the front end. And to me that's the key to all of this. That's what I argued in Revlon. Remember, though, I lost Revlon, so I'm prejudiced." Interview with Martin Lipton, Senior Partner, Wachtell, Lipton, Rosen \& Katz, in New York, NY (June 14, 2000).

244. Interview with Joseph H. Flom, Skadden, Arps, Slate, Meagher \& Flom, in New York, NY (June 15, 2000), transcript at 4 ("The way I look at it is very simple. If you're 
I observe that if there is "excessive" favoritism, Flom is correct that the back-end process would be too closed. For example, bringing the favored white knight into the hokey back-end process in Revlon did not instantly bring a whopper improvement of $50 \%$ as Lipton asserted, but only $5-6 \%{ }^{245}$ However, Lipton's "stalking horse" concerns still also ring true to a certain but merely limited extent.

The truth is somewhere in between and hence the Revlon solution of Middle Way favoritism, avoiding the problems of either extreme. Moderate favoritism would obviously help create the auction, but then not close down that process, if the favoritism is not so severe as to exclude subsequent other interested bidders. The line dividing under — from excessive — is purely an empirical matter.

In short, any form of "moderate" favoritism that a reasonable auctioneer would adopt based on common sense would likely be upheld. As I show below, however, only very slight favoritism would be embraced by reasonable auctioneers, hence the Delaware Middle Way view on favoritism significantly leans toward the Flom view. One possible short-hand maxim is that the back-end process should ultimately be "reasonably inclusive," hence giving a sufficient reasonable number of interested bidders a "fair opportunity" to win the auction, with only good faith "reasonable exclusions."

Economically, courts view "moderate" termination fees of strictly 3$4 \%$ as upheld. ${ }^{246}$ On the other hand, Van Gorkom and Revlon, as noted, censor high lock-up options on shares or crown jewel assets as "excessive" favoritism. Hence, economics lock-ups can give the first favored bidder only a relatively small bone. However, such a termination fee will still pay out to the favored bidder some significant modicum of firm "value," thus it operates with some limited deterrent effect of the process, but presumably this limited exclusion is a "reasonable exclusion," in light of the stalking horse problem.

Contractually, the answer is more complex. Barkan has clarified that the back-end process admits of reasonable flexibility and does not

selling the company, you've got to make sure that the premium is realized for your shareholders, because they're not going to have another chance. So you have to adopt a process, and your judgment is completely critical as to how you're going to structure it to try to get the best price.").

245. See Revlon, Inc. v. MacAndrews \& Forbes Holdings, Inc., 506 A.2d 173, 178 (Del. 1986) (noting that the white knight entered at $\$ 56, \$ 3$ above the hostile bid price).

246. See, e.g., McMillan v. Intercargo Corp., 768 A.2d 492, 505-506 (Del. Ch. 2000) (dismissing loyalty claim based on deal protection devices because inclusion of a "standard no-shop provision" and a 3.5\% termination fee do not provide "any support for the plaintiffs' Revlon claims.") 
necessarily always require a traditional auction-like auction solicitation (shopping) noisy process, hence in special cases where a company is "in play" (meaning that the players all know to make their best offers), a "noshop" clause (with "talking" rights) would be viewed as "moderate" favoritism. ${ }^{247}$ Rights of first refusal are also obviously moderate, since all bidders always have such implicit rights. ${ }^{248}$

On the other hand, invisible processes often might not satisfy Revlon. If in normal situations a more active shopping process ever is necessary for a reasonably fair process, then there must not be any closed down funny stuff going on with that shopping. ${ }^{249}$ Second, $Q V C$ strongly suggests that no-shop clauses with heavily restricted talking rights ("no-talk" clauses) would inherently be "excessive" favoritism. ${ }^{250}$

As noted, a Revlon reasonable auctioneer might presumably further impair the process for a legitimate "good faith" reason. For example, only if some bidder were highly problematic, say fundamentally very uncertain or acting in bad faith (perhaps attempting to expropriate firm confidential information), then one could maybe imagine a "full exclusion" as a reasonable/normal one.

I conclude that the expanded Revlon doctrine (like Van Gorkom) deals with the fact that the "takeover sale" process is obvious, or strictly a matter of common sense, essentially being nothing more than a reasonable backend process, with both Barkan and Lyondell making clear that some nice additional front-end would further dispel any process doubts. Again, with management discredited in the 1980s, the court made a trumpet call for better process in obvious situations, thereby hopefully curbing managerial reckless

247. See Barkan v. Amsted Indus., Inc., 567 A.2d 1279, 1287 (Del. 1989) ("When, however, the directors possess a body of reliable evidence with which to evaluate the fairness of a transaction, they may approve that transaction without conducting an active survey of the market."). Flexibility in Barkan is a good thing, since unnecessary expensive shopping that accomplishes no purposes simply in my view wastes corporate money and jeopardizes confidential proprietary information, with no real benefits.

248. In re Dollar Thrifty S'holder Litig., 14 A.3d 573, 608 (Del. Ch. 2010) ("[T]the plaintiffs claim that the Merger Agreement contained onerous deal protections such as ... a matching right provision that gave Hertz an unlimited, if extremely time constrained, chance to match any series of topping bids.").

249. See, e.g., In re Netsmart Technologies, Inc. S'holder Litig., 924 A.2d 171, 175 (Del. Ch. 2007) (describing how the board excluded strategic bidders from its process, illegitimately favoring only financial buyers, possibly because they would be kinder toward management); In re Holly Farms Corp. S'holder Litig., 564 A.2d 342, 344 (Del. Ch. 1989) (noting that the board "shopped", but unreasonably excluded a disfavored bidder from the process, by giving high lock-up options to its favored bidder).

250. See Paramount Communications Inc. v. QVC Network Inc., 637 A.2d 34, 39 (Del. 1994) (describing the provisions of the Original Merger Agreement between Paramount and Viacom). 
risk taking, where it was reasonably possible to do so.

$\square$ Revlon Triggers

To understand Revlon effects, one must understand the reasons for those effects, or the Revlon triggers. In Revlon mode, price and other short-term value become paramount, since the shareholders' "investment" / "property" is either eliminated in a cash-out deal or transformed into something fundamentally unrecognizable (at least to some extent) after an M\&A transaction with a completely different company, hence a manager's sole goal is to do right by the public shareholders' "investment", or property rights, beyond merely "voting," rather than, say, thinking about the broader prosperity of the firm and its constituencies. In this situation, the court no longer wants managers to take Unocal defensive positions, which would be pure pretext for selling out to a fake big bad wolf white knight, seizing corporate control, just as the disfavored hostile bidder would do.

As mentioned, the actual Revlon case viewed the Revlon triggers as the "inevitability" of a "break-up," a highly amorphous term. ${ }^{251}$ I take the view that the real Revlon trigger is what I call the "inevitability" of a "relative sale." First, that "inevitability" is judged largely through "common sense." For example, if management obviously opposes a "hostile" bidder (like in Revlon), then the "friendly" alternative seems obviously "inevitable." My invocation of corporate relativity makes one think of Judge Cardozo, who famously in Palsgraf elaborated:

The conduct of the defendant's guard, if a wrong in its relation to the holder of the package, was not a wrong in its relation to the plaintiff, standing far away. Relatively to her it was not negligence at all. Nothing in the situation gave notice that the falling package had in it the potency of peril to persons thus removed. Negligence is not actionable unless it involves the invasion of a legally protected interest, the violation of a right. 'Proof of negligence in the air, so to speak, will not do. ${ }^{252}$

By a "relative sale," I suggest that not all sales of a company are "investment" sales relative to the perspective of the existing shareholders, say should the "investment" remain fundamentally very similar at both the stock and firm levels. Revlon in my view involved a perfect "relative sale," which happened when management tried to sell the company in a cash-out sale to its favored white knight. If one were to $\mathrm{x}$-ray the public shareholders' "investment" in that case, a cash-out deal would obviously (A) destroy the stock part, and any possibility of commanding a future control premium in a

251. Revlon, Inc. v. MacAndrews \& Forbes Holdings, Inc., 506 A.2d 173, 182 (Del. 1986).

252. Palsgraf v. Long Island R. Co., 162 N.E. 99, 103, 341 (N.Y. 1928). 
later sale, and (B) fundamentally change the nature of the underlying corporation, with control obviously shifting to that favored white knight. Beyond Revlon, no one was certain what else could be considered a Revlon "relative sale", since one could imagine "investment" tinkering "relatively", in degrees, but not in absolutes. For example, under the pro-board Time ${ }^{253}$ and Ivanhoe ${ }^{254}$ doctrines, the court essentially took the view that if management's defensive measures kept the company "independent" (meaning without a hard "control shift"), then the "investment" (even if somewhat tinkered with in a "sale" situation) would not sufficiently be affected, hence the Revlon doctrine would not apply to what the court would view as a strictly Unocal fact pattern.

Of course, one could observe that those cases involve some slight or debatable shareholder "investment" tinkering, particularly Ivanhoe. At the stock level, giving a favored white knight a $49.7 \%$ ownership block ${ }^{255}$ would give a large enough block that would forever eliminate any chance of the public shareholders' "investment" commanding a control premium (even if such a right is somewhat speculative). At the firm level, the standstill agreement, preventing new white knight acquisitions to seize control, would expire after 10 years, ${ }^{256}$ and then also speculatively result in an eventual "control shift" in the not too distant future. Hence, the evolution of the Revlon doctrine ends not being as pro-shareholder as it might have been interpreted immediately after Revlon.

In contrast to Time and Ivanhoe, the subsequent pro-shareholder $Q V C^{257}$ case adds that an imminent hard "control shift" will trigger Revlon mode in a "relative sale, ${ }^{258}$ even falling short of a Revlon cash-out transaction. I use the word hard, since a separate Restaurant Associates ${ }^{259}$ case teaches that a soft "control shift," where management had already owned $48 \%$ practical control of a company pre-deal, ${ }^{260}$ would not be viewed as a clear "relative sale." It is also worth mentioning that in the recent $C \& J$ Energy case, ${ }^{261}$ the court even perhaps in my view toyed with the idea that a "control shift"

253. Paramount Commc'ns, Inc. v. Time Inc., 571 A.2d 1140, 1140 (Del. 1989).

254. Ivanhoe Partners v. Newmont Min. Corp., 535 A.2d 1334 (Del. 1987).

255. Id. at 1337.

256. Id. at 1338 .

257. Paramount Communications Inc. v. QVC Network Inc., 637 A.2d 34, 34 (Del. 1994).

258. See id. at 46 ("[M] acmillan and Barkan are clear in holding that a change of control imposes on directors the obligation to obtain the best value reasonably available to the stockholders ....").

259. Freedman v. Restaurant Associates Industries, Inc., 1987 WL 14323 (Del. Ch. 1987).

260. Id. at $* 2$.

261. C\&J Energy Services, Inc. v. City of Miami Gen. Employees' Ret. Trust, 107 A.3d 1049 (Del. 2014). 
maybe one day would not trigger Revlon mode, with the right contractual protections softening and limiting controller power. ${ }^{262}$

In conclusion, then, I observe that the real Revlon trigger is not just a "relative sale," but it must be a very clear "relative sale," with the court drawing the line with Restaurant Associates, Time, and Ivanhoe as merely debatably "relative," versus $Q V C$ and Revlon as clearly "relative." Note that in the Delaware "independent" company system, the vast majority of "sale" deals would presumably be debatably "non-relative," and hence Unocal rather than Revlon mode cases. All this later jurisprudence then severely contracted the possibilities for invoking the Revlon doctrine.

\section{iii. Omnicare (Act I and a Half)}

In Omnicare, the company was in a desperate situation, hence the board sought to lock-in a "whopper" deal offer that came along, ${ }^{263}$ by disabling dual board and shareholder contractual "outs", ${ }^{264}$ should a superior deal surface. Although technically outside Revlon mode without a "control shift," 265 the court held that such 100\% governance "lock-ups," foreclosing rival bidders from process access, were fundamentally impermissible, no matter whether in Unocal or Revlon mode. ${ }^{266}$ Of course, there was some kind of "sale" plan that was debatably Revlon "relative," hence I observe that one could view Omnicare stronger "governance" lock-ups scrutiny (over and above Unocal but below Revlon) as Act I and a Half.

262. If a controller is "contractually" kept passive, then in some sense, the "control shift" is not so hard.

263. See Omnicare, Inc. v. NCS Healthcare, Inc., 818 A.2d 914, 922 (Del. 2003) (“On June 25 , the economic terms of the Genesis proposal included repayment of the NCS senior debt in full, full assumption of trade credit obligations, an exchange offer or direct purchase of the NCS Notes providing NCS Noteholders with a combination of cash and Genesis common stock equal to the par value of the NCS Notes (not including accrued interest), and $\$ 20$ million in value for the NCS common stock.").

264. See id. at 933 ("Genesis insisted the merger agreement include a Section 251(c) clause, mandating its submission for a stockholder vote even if the board's recommendation was withdrawn. Genesis further insisted that the merger agreement omit any effective fiduciary out clause.").

265. See id. at 929 ("[B]ecause the stock-for-stock merger between Genesis and NCS did not result in a change of control, the NCS directors' duties under Revlon were not triggered by the decision to merge with Genesis.").

266. See id. at 939 ("In the context of this preclusive and coercive lock up case, the protection of Genesis' contractual expectations must yield to the supervening responsibility of the directors to discharge their fiduciary duties on a continuing basis. The merger agreement and voting agreements, as they were combined to operate in concert in this case, are inconsistent with the NCS directors' fiduciary duties."). 


\section{Cleansing}

Whereas charter exculpations would reverse Van Gorkom "gross negligence," all that did nothing for "disloyalty" (including Revlon). ${ }^{267}$ As the 1980s' very scary storms (for managers) calmed down, courts looked for new ways of ensuring "fair" deals for all, but with more litigation comfort for corporate managerial defendants, particularly given that courts in competence are not truly experts on "fairness valuations.".

In recent years, then, vertical "conflicts" duties have migrated first from $100 \%$ void toward merely voidable (as noted above) and then toward "cleansings" (using various forms of fully informed "independent processes"). ${ }^{268}$ Kraakman calls these mechanisms as forms of "trusteeship" strategies, which I observe solve any "agency problems," by reducing agent "discretion" (as opposed to stick fiduciary duty breach "liabilities"). Cleansing "effects" (if done right), apart from Unocal, ${ }^{269}$ can revert the disloyalty scrutiny from entire fairness to the business judgment rule. ${ }^{270}$

Notice how as Revlon further expanded vertical fiduciary duties, the pro-board subsequent developments of exculpations and cleansings together effectively also proportionately expanded the board's business judgement rule "shield." This movement has ultimately facilitated that Middle Way between 100\% disloyalty "prohibitions" and blanket disloyalty "exculpations." Hopefully, these strategies sufficiently reduce conflicts suspicions so that, at least in most cases, the good empirically now outweighs the bad. But how?

For either road, courts would want genuine disinterestedness, as opposed to token independence. Hence, courts ideally would want $100 \%$

267. See Berry, supra note 164, at 1126-27 ("[S]ection 102(b)(7) provides that directors are not protected from liability arising from their bad faith conduct."). "Some Delaware courts have concluded that the duty of good faith is merely a subset of the duty of loyalty." Id. at 1128, n. 18 .

268. See Del Code Ann. Tit. $8, \S 144$ (statutory requirements for "cleansing" certain kinds of director "conflicts"); Cooke v. Oolie, 2000 WL 710199 (Del. Ch. 2000) (broadening the scope of "conflicts" that can be so "cleansed").

269. See Bainbridge, supra note 40, at 819 (In Unocal cases, "the board's burden of proof is more easily carried if the key decisions are made by independent directors."). I observe that Unocal provides that the imprimatur of a majority of disinterested directors merely results in additional board deference rather than $100 \%$ scrutiny reversal, presumably since board "defenses" are "strategic" as much as "tainted," hence requiring simultaneous mixed "insider" and "outsider" competence, in contrast to "disloyalty."

270. One could imagine lots of gadfly lawsuits, even with arguably fair deals, which prodefendant attorney called a terrible burden on the economy. Apparently, when disloyalty intrusion was too strong, $95 \%$ of deals were sued. PLI Conference, Delaware Law Developments 2017: What All Business Lawyers Need to Know. 
independence with virtually no insiders involved "from the outset," ${ }^{271}$ not "too much" money, power, or family ties between independent directors and any insiders, ${ }^{272}$ and no domination, muscling, or coercion by the insiders. ${ }^{273}$ More important, courts would require real "muscle" behind that independence, meaning an active quasi-arm's length (rather than passive) directorial bargaining process. ${ }^{274}$ All this makes me think of Antisthenes, a first-generation Socratic proclaimed, who similarly praised independence combined with strength.

There might be a couple objections to the rise of cleansing mechanisms. First, I once heard it asked in a recent PLI conference, what if an insider were to say, "I'm stealing, I'm a bad guy, but I'm transparent!" 275 Second, Eisenberg once rolled his eyes at the idea of what he saw as "chummy" disinterested mechanisms. ${ }^{276}$ In the current times, however, I have great faith in the promise of cleansing mechanisms, in contrast with the bad old days.

271. Note how in Weinberger, the court did not give any cleansing effect when trained directors participated in the process and withdraw only "at the end."

272. Since this is not a none-or-all matter, courts invariably must confront the question of what level of "ties" are acceptable versus illegitimate. See Anatomy, supra note 15, at $\S 3.2$ ("Truly independent directors are board members who are not strongly tied by high-powered financial incentives to any of the company's constituencies but who are motivated principally by ethical and reputational concerns."); Kahn v. Tremont Corp. 693 A.2d 422, 429-30 (Del. 1997) (disqualifying the independent committee members with business client ties to the insiders). However, some level of "financial ties" to the corporation might make sense for, say, a 5\% institutional shareholder appointed "independent" director, since some "muscle" wouldn't compromise (and would even facilitate) his "objectivity" in the face of vertical or horizontal conflicts. Even controller appointment of the "independent" directors would often not be viewed as compromising "objectivity", absent domination, muscling or coercion, since "appointment" by itself is the controller's legitimate "governance right," by virtue of its "control." However, perhaps certain societies with empirical problems might view even "appointment" alone under some form of "muscling" presumption. See Ventoruzzo, supra note 89 , at 263 .

273. See Kahn v. Lynch Communication Systems, Inc. 638 A.2d 1110, 1114 (Del. 1994) (censoring the insiders from telling the independent committee what to do).

274. See Krasner v. Moffett, 826 A.2d 277, 284-85 (Del. 2003) ("[T] he FSC directors, not the plaintiffs, bear the burden of proving that the MEC merger was approved by a committee of disinterested directors, acting independently, with real bargaining power to negotiate the terms of the merger."); Rosenblatt v. Getty Oil Co., 493 A.2d 929, 937-38 (Del. 1985) ("[I]t is clear that these contending parties to the merger in fact exerted their bargaining power against one another at arm's length. This is of considerable importance when addressing ultimate questions of fairness, since it may give rise to the proposition that the directors' actions are more appropriately measured by business judgment standards.").

275. PLI Conference, supra note 270.

276. See Melvin Eisenberg, Self-Interested Transactions in Corporate Law, 13 J. CoRP. L. 997, 1002 (1988) ("[D]irectors, by virtue of their collegial relationships, are unlikely to treat one of their number with the degree of wariness with which they would approach a transaction with a third party.”). 
A priori, adequate cleansing mechanisms should work better in terms of shrinking managerial powers and expanding institutional shareholder powers. ${ }^{277}$ Stronger relative "shareholder power" is a strong argument for weaker corporate regulatory law. ${ }^{278}$ Empirically, I believe that there is strong evidence today that sophisticated institutional shareholders are influencing independent boards and using their muscle to bargain fiercely for their shortterm "investment" property rights in tainted deal situations. For example, the independent board recently aggressively pushed back for more minority "consideration" against the founder's proposed Nordstrom privatization plan. $^{279}$

In any event, while some speak about "the rise and fall of the Revlon doctrine," 280 believing that judges today are less likely to get "directly" involved, I view Revlon as being very much alive today, but more in the minds of the independent processes of the landscape, rather than micromanaged by judges. I observe something of a dance, where the Delaware judges "calm down" (which I once heard a Delaware judge express about the evolution of the Revlon doctrine) - and I add, as the regulated entities exhibit fewer and fewer governance problems (and the independent process seems more and more muscular). ${ }^{281}$ I might add that the highest level of the life of the judiciary is to implant their vision in the spirit of their people.

\section{Duty of Corporate Monitoring}

Although a subset of both the duties of care and loyalty, it makes some analytic sense to consider the duty of corporate monitoring as its own category. The duty basically deals with a manager's duties, absent business

277. See supra Section II.

278. See Anatomy, supra note 15, at $\S 2.6$ ("Where ownership of shares is more diffuse, however, governance mechanisms are less effective, and there is more need for regulatory mechanisms to take force.").

279. Benjamin Romano, No Deal: Nordstrom family's price not enough for board, SEATtLe TimeS, Mar. 20, 2018, https://www.seattletimes.com/business/retail/nordstromfamily-ends-quest-to-take-seattle-retailer-private/ [https://perma.cc/4UZ3-9H34] ("Nordstrom family members were apparently unwilling or unable to substantially boost their $\$ 50$ a-share offer for the company that bears their name, prompting the retailer's independent directors Tuesday to terminate buyout discussions.").

280. Lynn A. Stout, Share Price as a Poor Criterion for Good Corporate Law, 3 BERKELEY Bus. L. J. 43, 43 (2005).

281. More recent Revlon cases exhibit that objective cool head and steady hand, notwithstanding flexibility and cleansing. See, e.g., Barkan, 567 A.2d 1279 (where Revlon effects flexibility nonetheless maximized deal value); Dollar, 13 A.3d at 600 (where deal certainty would add Revlon short-term value). 
decisions, to actively and reasonably monitor a corporation for illegalities. ${ }^{282}$

Philosophically, the idea of "monitoring" is that management cannot "nonfeasantly" stick its head in the sand in the face of corporate "illegalities." Like all duties, "monitoring" ideals give rise to a conundrum. On the one hand, without "monitoring" ideals, managers might ignore firm "illegalities," thus harming the broader society (but perhaps not the firm itself, if those "illegalities" add "monetary value"). On the other hand, the law mandating too much "monitoring" can also create problems, by overdeterring management as well as disrupting firm "harmony."

Prior to the Enron era, Allis-Chalmers imposed a very soft managerial duty to monitor for illegalities, in the absence of very severe red flags. ${ }^{283}$ While illegal, price fixing in those early years was rampant and would not devastate the firm or the larger economy. In the post-Enron era, witnessing the firm and systemic catastrophic consequences of managerial nonfeasance in the face of certain terrible corporate illegalities, Delaware courts have since embraced Caremark duties principles, with a stronger trumpet call for compliance obligations, even if hortatory and typically deferring to the board's "good faith" judgment that its compliance policies are sufficient, especially if there are charter exculpations. ${ }^{284}$ Caremark notes that only systematic monitoring failures could be viewed as "bad faith," 285 a core vulnerability of even charter exculpations.

I would then imagine likely incurring the court's Caremark monitoring angers only in catastrophic Enron-like situations, or something else that is highly abusive in terms of disrupting the firm or the larger economy. Under Caremark, a "reasonable" compliance philosophy and praxis should hopefully go a long way to head off most "nonfeasance" violations. Of course, the Delaware courts might one day have to approach a question on "the line" and decide just how terrible is terrible enough at the margins, giving due consideration to the "opposing" forces discussed above. However, in a hard-working good faith land like ours, one would expect that, for the most part, Caremark's merely somewhat hortatory ideals should be

282. See Claire A. Hill \& Brett H. McDonnell, Reconsidering Board Oversight Duties after the Financial Crisis, 2013 U. ILL. L. REV. 859, 873 (2013) ("[A]pparently, the directors owe a duty to monitor for illegality even if the illegality offers a net pecuniary benefit to shareholders.”). But see In re Citigroup Inc. Shareholder Derivative Litigation, 964 A.2d 106, 126 (Del. Ch. 2009) (noting that there is no duty to monitor for business risks).

283. See Graham v. Allis-Chalmers Mfg. Co., 41 Del. Ch. 78, 84 (Del. 1963) (holding that there were no red flags of price fixing by the directors, even with prior violations).

284. See In re Caremark Intern. Inc. Deriv. Litig., 698 A.2d 959, 972 (Del. Ch. 1996) (deferring to the board's good faith determinations of compliance).

285. Id. at 971 ("[O]nly a sustained or systematic failure of the board to exercise oversight ... will establish the lack of good faith ....”). 
helpful, particularly with the provisions of the federal SEC Sarbanes-Oxley applying on top of Caremark. ${ }^{286}$

\section{B. The Horizontal Axis}

\section{a. Governance}

Controllers, by definition, obviously have sufficient ownership to control "legal" corporate governance. Obviously, majority "control" holders are controllers, mathematically speaking. However, in Delaware, others could also be viewed as controllers, with say a large stake (say 35-40+\%), combined with "muscling" attempts (like making threats, bossing around management all the time, over-aggressive tactics in conflicted decisions, etc.). On the other hand, mere director "appointment" by itself is typically insufficient to give rise to controller status in Delaware, since all that is presumably part of a large shareholder's legitimate "property rights."

First, I consider "the means" of a controller's "control" acquisition, such as, say, converting the corporate capitalization into "dual-class stock," essentially a form of "controlling minority structure" ("CMS") perhaps raising firm Kaldor-Hicks "inefficiency" problems lacking proportionate "skin in the game." 287 Hence, SRO regulators in America often demand that CMS "control" be fairly acquired pre-IPO with an ex ante meeting of the minds (where IPO investors will simply pay "less price" for "less control"). ${ }^{288}$ From the state law perspective, though, that "recapitalization" re-allocation of "governance" power is arguably "democratically" adopted (as the will of all shareholders). ${ }^{289}$ Hence, Delaware law might permit certain dual-class "recapitalizations" post-IPO, if there is not too much "coercion" of the shareholders. ${ }^{290}$

Second, I consider the "limits" of a controller's ability to adopt

286. See Regina F. Burch, Director Oversight and Monitoring: The Standard of Care and the Standard of Liability Post-Enron, 6 WYO. L. REV. 481, 508-09 (2006) (noting how Sarbanes-Oxley imposes stronger monitoring duties, beyond Caremark).

287. For example, a controller with a $5 \%$ economic stake and $51 \%$ control would not have the same "firm maximization" as a regular shareholder.

288. See Commentaries and Cases (Teacher's Manual), supra note 156, $\S 5.7 .3$ ("The theory is that at the IPO managers will adopt the capital structures that maximize the size of the overall pie, whereas at midstream you can bribe minority shareholders to give you the votes.").

289. I call this the corporate democracy problem of shareholders being "free" to relinquish their "freedoms?"

290. See Lacos Land v. Arden Group, 517 A.2d 271 (Del. Ch. 1986) (shareholder "coercion" in a recapitalization). 
governance. Controllers, by definition, obviously have sufficient ownership to control "legal" corporate governance. However, Hollinger nonetheless teaches that they must not "inequitably" oppressively adopt governance provisions (in violation of the spirit of either duties or the contract). ${ }^{291}$

Beyond controllers, horizontal "governance" rights and duties could be made distinct across various public shareholders, if there are charter-adopted different "classes" of stock ${ }^{292}$ (meaning a sub-division of stock with its own distinctive governance "rights" and "limits").

\section{b. Regulations}

As with vertical, horizontal relationships are subject to regulatory corporate law, typically raising disloyalty more than care issues. While the minority stockholders typically owe no fiduciary duties (subject perhaps to a few narrow pockets such as vote buying), ${ }^{293}$ controller disloyalty is a much more ambiguous and complicated issue.

Philosophically speaking, some degree of controller self-interest is arguably justifiable (just like managerial self-interest). In contrast to managers, controllers, as near- or majority-owners (assuming their control is fairly acquired), have their legitimate disproportionately "costlier" and "more valuable" property rights as principals ${ }^{294}$ and further are not paid agents of the minority shareholders, ${ }^{295}$ in contrast with managers. Moreover, from a Kaldor-Hicks perspective, absent CMS, controllers as shareholders should have aligned interests with the minority shareholders, since in

291. See supra note 138 and accompanying text.

292. See Del Code. Ann. Tit. 8 § 151(a) (2018) ("Every corporation may issue 1 or more classes of stock or 1 or more series of stock within any class thereof, any or all of which classes may be of stock with par value or stock without par value and which classes or series may have such voting powers, full or limited, or no voting powers, and such designations, preferences and relative, participating, optional or other special rights, and qualifications, limitations or restrictions thereof, as shall be stated and expressed in the certificate of incorporation or of any amendment thereto, or in the resolution or resolutions providing for the issue of such stock adopted by the board of directors pursuant to authority expressly vested in it by the provisions of its certificate of incorporation.").

293. The basic law is that if the public shareholders "sell" their vote, all that must "advance" shareholder interests. See Schreiber v. Carney, 447 A.2d 17 (Del. Ch. 1982).

294. I say "costlier," since buying "control" usually means paying a hefty control premium, and "more valuable," since control gives disproportionate advantages that are not possible with minority ownership, such as access to assets, full governance control, etc.

295. See Greta M. Fung, A Common Goal from Two Different Paths: Protection of Minority Shareholders in Delaware and Canada, 57 AlB. L. REv. 41, 44 (1993) (noting that controllers do not intend to benefit minority shareholders); Jedwab v. MGM Grand Hotels, Inc., 509 A.2d 584, 598 (1986) (stating that controllers do not have to sacrifice their selfinterest for the minority shareholders). 
supposedly "equal situations," ${ }^{, 296}$ all shareholders should have both stock investment and firm value maximization incentives. ${ }^{297}$ Obviously, controllers (just like institutional investors) should easily overcome any "coordination" problems (in contrast to ma and pa public shareholders). Hence, in quite a few normal situations, controllers might arguably even have "superior" incentives to widely dispersed public shareholders.

On the other hand, there are both controller Kaldor-Hicks and Pareto efficiency problems. First, as noted, any form of CMS (even if fairly acquired) would raise concerns that controllers would have sub-optimal Kaldor-Hicks "firm maximization" incentives. Moreover, even without CMS, if a controller stands to usurp freeze-outs benefits, then it could afford to sacrifice "firm" value. Second, Pareto-wise, controllers might overaggressively grab "too much" for themselves, since they hold all the keys against a completely powerless minority, ${ }^{298}$ in contrast with the more equal vertical axis (shareholders have their political voices) and external axis (creditors can contractually bargain ex ante). To make matters worse, empirically, controller abuses are (or at least were) a problematic area for our society. ${ }^{299}$

Hence, controllers at times are viewed as trustees, who should not be too self-interested. ${ }^{300}$ However, what is "too much" is somewhat amorphous, since it involves an "allocational" Pareto efficiency question about the relative rights of each horizontal axis side, without an absolute objective marker, in contrast with the "pie maximization" concept of Kaldor-Hicks efficiency. ${ }^{301}$

296. See Commentaries and Cases, supra note 156, $\S 7.4 .1$ (observing how the interests of the controller and the minority shareholders were aligned in equal dividend situations in the famous Sinclair case).

297. See Henry Hansmann, Ownership of the Firm, 4 J.L. ECON. \& ORG. 267, 283 (1988) ("Another great strength of investor-owned firms is the fact that the owners generally share a single, well-defined objective: to maximize the net present value of the firm's earnings per dollar invested.").

298. See William Z. Pentelovich \& Cynthia F. Gilbertson, Upholding Shareholders' Interests: 20 Years with the Minnesota Business Corporations Act, 58-OCT BENCH \& B. MinN. 19 (2001) ("The protections of corporate democracy often provide no relief for minority shareholders oppressed by the majority."); Zipora Cohen, Fiduciary Duties of Controlling Shareholders: A Comparative View, 12 U. Pa. J. Int'1 Bus. L. 379, 380 (1991) (noting that controllers control the property of the minority shareholders and make decisions on their behalf).

299. See Krebs, supra note 54, at 945 (noting an increase in freeze-outs in the 1970s).

300. See Zipora Cohen, Fiduciary Duties of Controlling Shareholders: A Comparative View, 12 U. PA. J. INT'L BuS. L. 379, 380 (1991) (noting that controllers control the property of the minority shareholders and make decisions on their behalf).

301. 'Kaldor-Hicks efficiency is to be contrasted with 'Pareto efficiency,' under which a change is efficient only if the pie increases and every constituent's piece of pie is also 
I might additionally point out how horizontally, in contrast to the vertical axis, there are much fewer market and democracy checks (given that controllers cannot easily be fired or voted out). That might explain why Delaware judges adopt a somewhat more aggressive "regulation" pattern along the horizontal axis.

\section{Weinberger Doctrine - Sales and Oppositions}

The Weinberger case (and subsequent Weinberger jurisprudence) have held that virtually all forms of controller "conflicted" freeze-outs would merit the "intrusive" entire fairness scrutiny (with the burden shifted to the defendant). Just like with vertical disloyalty, 100\% horizontal condemnation would go too far in the shareholder direction, since horizontal conflicts too can ultimately be good. ${ }^{302}$

Delaware courts usually view suspicious freeze-outs, in terms of the Sinclair benefit-detriment test, meaning only if the controller "receives something [differential] from the [corporation] to the exclusion of, and detriment to, minority shareholders." ${ }^{303}$ In plain language, all this basically means that the controller "disproportionately" seizes more of something than the minority. Examples have included any forms of "differential" deals, ${ }^{304}$ including freeze-out mergers in Weinberger, ${ }^{305}$ being on both sides of the transaction in Tremont, ${ }^{306}$ differential consideration in a sale of control in

increased." See Commentaries and Cases, supra note 156, Introduction, n.1.

302. I observe a few possible good outcomes for freeze-out mergers. For example, if a controller is abusive, perhaps the minority is better off being taken out of the corporation, particularly with statutory appraisal to protect the "fair value" price of their shares. From the firm perspective, perhaps the minority could be gadflies, suing and holding up "value" controller deals, in a greedy self-interested way. Apart from that, one could imagine in private equity buy-out transactions how a controller could implement superior "value" plans with $100 \%$ control, and no minority or market shot term bias oppositions. Some corporations also are possibly better off going private, due to SEC regulatory cost savings or advantages of keeping their proprietary information more secret, without SEC public filings.

303. Id. at $\S 7.4 .1$.

304. In contrast, under the market rule, as might be expected from the Sinclair test, a "nondifferential" sale of control is typically viewed as part of the old controller's property rights, hence such a claim is typically dismissible, subject perhaps to buyer-side freeze-outs (discussed below). See Abraham v. Emerson Radio Corp. 901 A.2d 751, 758 (Del. Ch. 2006) ("The essence of Emerson's argument that the complaint fails to state a claim is simple: under Delaware law, Emerson was free, as a general matter, to sell its majority bloc in Sport Supply for a premium that was not shared with the other Sport Supply stockholders.").

305. See Weinberger v. UOP, Inc., 457 A.2d 701 (Del. 1983) (involving a freeze-out merger that cashed out the minority shareholders, with concerns that price was too low).

306. See Kahn v. Tremont Corp., 694 A.2d 422 (Del. 1997) (sale from one corporation to a second corporation controlled by the first corporation's controlling shareholder). 
John $Q$ Hammons ${ }^{307}$ or even seizing a corporate sale opportunity in Hollinger. While it is worth pointing out, as mentioned, how "control" fundamentally is disproportionately "costlier" and "more valuable" (thus, perhaps controllers should legitimately seize "disproportionately" more), controller freeze-outs, without as many market and democratic checks as with managers, do also raise abuse concerns, hence Weinberger "intrusion" embraces a fire-for-fire style of thinking.

In terms of effects, first, Weinberger "fairness" review clearly contemplates some controller duty to maximize minority public shareholder interests (typically in a deal situation), like in the vertical Revlon context. Effectively, Weinberger duties then should, to some extent, expand minority Pareto "allocational" rights.

As the means to the above end, Kraakman observes how Weinberger broadened minority "valuation" in so many ways. ${ }^{308}$ Weinberger opened the door to more scientific "methods" of valuation, beyond just the old Delaware block method. $^{309}$ Perhaps more significant, Weinberger took a minority generous view of the objects of the new science, i.e., the minority's "property rights" to be valued. Weinberger seemed to read that minority maximization duty as giving a control premium or even certain "provable" deal benefits (say certain strategic synergies), though courts have since perhaps waffled on the exact extent of that minority generous Weinberger reading. ${ }^{310}$ Second, Weinberger also made noises about possible broader "equitable remedies" (such as injunctions or rescissions) for even some "conflicts" alone. However, many argued that Weinberger over-protected minority rights. Since the old days, then, the court has clearly backed off Weinberger "equitable remedies" (absent something terrible such as fraud) and I have heard it said by some that the court has even waffled about lighter "valuations," at times rejecting deal "benefits." 311

So far we have discussed controllers rights to sell, but what about its

307. See In re John Q. Hammons Hotels Inc. S'holder Litig., 2009 WL 3165613 (Del. Ch. 2009) (controller and minority shareholders received differential consideration in a sale of control).

308. See Commentaries and Cases (Teacher's Manual), supra note 156, $\S 7.4$ (discussing the evolution of Weinberger "valuation" principles).

309. See Weinberger., 457 A.2d at 712 ("However, to the extent [the block method] excludes other generally accepted techniques used in the financial community and the courts, it is now clearly outmoded. It is time we recognize this in appraisal and other stock valuation proceedings and bring our law current on the subject.").

310. See Commentaries and Cases (Teacher's Manual), supra note 156, $\S 11.9$ (observing three readings of Weinberger "price" maximization - (a) minority discount, (b) control premium or even (c) "provable" deal benefits).

311. See id. (pointing out that the later Rabkin case suggests that the deal "benefits" reading is now on shaky ground). 
opposite, i.e., rights not to sell, if a controller unwanted sale would "differentially" benefit the minority shareholders, at the expense of the controller? I observe that the law works exactly as the inverse of the sale laws. If the controller "non-differentially" has no (or has abandoned) a sale plan of its own, then one could imagine a Delaware court embracing the Abraham "market rule," thus letting a controller simply oppose any unwanted sales. ${ }^{312}$ Under Mendel $^{313}$ and Orman, ${ }^{314}$ however, when controllers initially have their own "differential" sale plan, controllers have their property rights merely to oppose unwanted sales, provided that they implement sufficient Weinberger-style "independent" processes and do not "abusively" try to push through their own conflicted plan. ${ }^{315}$

\section{Cleansing Weinberger}

Just like in the vertical disloyalty context, subsequent post-Weinberger case law has evolved in the direction of the fair process cleansing principles. Today, per John Q Hammons ${ }^{316}$ and CNX Gas, ${ }^{317}$ all forms of Delaware controller disloyalty under the Weinberger doctrine are subject to a fair process cleansing, but with more conditions for reverting to the business judgment rule than in the strictly directorial context, given the exigencies of the conflicted controller anti-democratic abuse concerns. Perfectly cleansing conflicted controller deals now requires, after full and fair disclosures, a noncoercive $^{318}$ vote of a majority of disinterested directors, plus the "non-

312. See Abraham v. Emerson Radio Corp., 901 A.2d 751 (Del. Ch. 2006) (illustrating the market rule at work, absent seller- or buyer-side "abuses").

313. See Mendel v. Carroll, 651 A.2d 297, 298 (Del. Ch. 1994) (where the controller, after abandoning its purchase plan, "would not voluntarily sell [company] stock").

314. See Orman v. Cullman, 794 A.2d 5, 17 (Del. Ch. 2003) (upholding a controller sale agreement, which would also veto alternative deals for a period of time, but subject to a nonabusive adequate "independent process").

315. See McMullin v. Beran, 765 A.2d 910 (Del. 2000) (controller abusively tried to push through its own "differential" sale plan, while vetoing alternative deals, without an adequate "independent process").

316. See In re John Q. Hammons Hotels Inc. S'holder Litig., 2009 WL 3165613 at*12 (holding that the entire fairness standard was appropriate).

317. In re CNX Gas Corp. S'Holders Litig., 4 A.3d 397, 412-13 (Del. Ch. 2010) (holding that under the unified standard for reviewing controlling stockholder freezeouts, the business judgment rule applies when a freeze-out is conditioned on both the affirmative recommendation of a special committee and the approval of a majority of the unaffiliated stockholders).

318. Id. at 411 (noting that a short-form merger must be at the first step tender office price). 
waivable"319 approval of a majority of disinterested minority shareholders. ${ }^{320}$ The same directorial conditions for genuine independence would apply to controllers. ${ }^{321}$ If perfectly cleansed, then the business judgment rule would, in turn, permit controllers to dodge the "amorphous" Pareto questions under Weinberger entire fairness. Like in the vertical context, while Weinberger expanded horizontal fiduciary duties, the pro-controller subsequent developments of cleansings effectively also proportionately expanded the controller's business judgement rule "shield." In essence, the rise of these new perfect cleansing mechanisms strike a Middle Way in Weinberger's fire-for-fire philosophy.

Again, as institutional shareholders rise, I expect that they will influence independent boards and use their muscle to bargain fiercely for their short term "investment" property rights, thus limiting horizontal (just like vertical) agency problems. Hence, while some cry out for the rise and fall of Weinberger (like Revlon), Weinberger is very much alive today in the same sense as Revlon.

\section{Bypassing Weinberger}

From the controller's perspective, "perfect cleansing" might at last yield business judgment rule review, but at the cost of relinquishing its deal process control, hence controllers began to look for paths around Weinberger altogether. It is worth noting as an exception to Weinberger that traditionally, under Glassman, $\S 253$ short-form freeze-out mergers (where the minority takeout was less than $10 \%$ ) were exempted from Weinberger entire fairness, even without "cleansing." 322 Presumably, the philosophy here is that small minority equals small abuses, especially in light of the possible good of freeze-out mergers (discussed above).

However, very often, a controller cannot get up to Glassman $90 \%$

319. See PLI Conference, Delaware Law Developments 2017: What All Business Lawyers Need to Know (while not so clear when the freeze-out process starts, if non-waivability is missed at the outset, one cannot put the genie back in the bottle).

320. Nonetheless, with some lesser moderate cleansing, it might be possible to shift the burden of proof to the plaintiff, under the Lynch doctrine. See Hammons, 2009 WL 3165613 at *10 ("“[A]pproval of the transaction by an independent committee of directors or an informed majority of minority shareholders' would shift the burden of proof on the issue of fairness to the plaintiff, but would not change that entire fairness was the standard of review."). However, the court then would still undertake some form of somewhat "amorphous" Pareto analysis, in contrast with the perfect cleansing context.

321. See supra notes 271272-274 and accompanying text.

322. See Glassman v. Unocal Exploration Corp., 777 A.2d 242, 247 (Del. 2001) (stating "If a corporate fiduciary follows the truncated process authorized by $\S 253$, it will not be able to establish the fair dealing prong of entire fairness."). 
territory without a first step tender offer, which could be viewed as coercive for obvious reasons. As mentioned, if a controller undertakes such a first step tender offer, CNX Gas will subject that to the Weinberger doctrine, thus requiring ideally perfect cleansing. ${ }^{323}$ However, for aspiring would-be controllers who start as non-controllers, they can as of recent years potentially reach Glassman short form merger territory with the new $\S$ 251(h) short form merger statute, ${ }^{324}$ subject to its conditions aimed at ensuring the integrity of the shareholder will supporting that transaction. Since 251(h) requires $100 \%$ buy-out offers, shareholders are not harmed or "diluted," while 251(h) facilitating the two-tier bid should increase the universe of available bidders, ultimately raising shareholder "price." Whether starting as a controller or non-controller, whether Weinberger or non-Weinberger, clearly the court's goal is to ensure a fair freeze-out process, without any funny stuff going on. All Weinberger (and bypassing Weinberger) jurisprudence thus falls within this unitary maxim.

\section{Looting}

Weinberger is limited as a doctrine about conflicted controller sellers. A second controller sale of control problem happens in the context of abusive buyers, who are viewed as "looters." By looting, I mean an abusive buyer (rather than seller) stealing "value" from the minority in another "amorphous" Pareto inefficient way. Hence, looting is really nothing more than a buyer-side controller freeze-out.

Delaware law is less suspicious of these buyer-side controller freezeouts than in the Weinberger seller context. First, practically speaking, it is very difficult for sellers to know which persons are or are not looters, since looters often do not wear signs. Second, even if it could be done, too much "due diligence" pressures on every minor matter might over-deter "value" sales of control. Hence, Abraham ${ }^{325}$ requires significant investigation of buyer looting only with serious red flags. ${ }^{326}$ Presumably, a care issue, unless a terrible bad faith error, a charter exculpation should give the old controller somewhat more latitude in its investigation here.

323. See CNX Gas, 4 A.3d at 410.

324. Del Code. Ann. Tit. 8 § 251(h).

325. See Abraham v. Emerson Radio Corp., 901 A.2d 751 (Del. Ch. 2006) (stating that the controller must have reason to believe that the buyer is questionable).

326. See id. at 759 (stating that there are no looting red flags). Certain other states might have a different investigation philosophy, at least in pressing situations. See Perlman v. Feldmann, 219 F.2d 173 (2d Cir. 1955) (old controller held liable for buyer's side "looting" in a desperate war-time situation, with perhaps more empirical rates of buyer-side freezeouts). 


\section{The External Axis}

The Delaware corporate law "external" axis is complicated, since it potentially broadly encompasses any imaginable constituency viewed by the judiciary as "outside" of the corporation, such as creditors, preferred stock, employees, raiders, suppliers, customers, charitable beneficiaries and even the government/society. As I discuss in Part II, different nations and even U.S. states might have different views of exactly "who" is internal versus external.

Most "external" axis law in America has typically centered on complex firm-creditor relationships. On the one hand, Delaware corporate law is predominantly "internal," particularly when "internal" conflicts with "external." First, from the Kaldor-Hicks perspective, "shareholders" (with both upside and downside) typically have better "firm" maximization incentives than "creditors." 327 Even from a Pareto perspective, it might be preferable to put shareholders first in normal situations. Contractual creditors have a choice, can do due diligence and then negotiate for desired ex ante contractual protections, in contrast to equity who depend on strictly corporate law "protections." On the other hand, some "external" benevolence (whether mandatory or hortatory) should facilitate corporate "internalities," in the big picture, say, by not over-deterring creditor contracting.

There are typically no "mandatory" Delaware fiduciary duties running "externally" to creditors in normal situations. ${ }^{328}$ However, under Credit Lyonnais, insiders suddenly owe at least some duties to creditors (and presumably the preferred) once "in the vicinity of insolvency." 329 Kraakman explains that this one-off "external" duty is due to the "inefficiencies" of this particular situation in a shareholder-centric law, where shareholder insolvency-specific "over-aggressive" risk taking incentives could become

327. See John H. Matheson \& Brent A. Olson, Corporate law and the Longterm Shareholder Model of Corporate Governance, 76 MINN. L. REV. 1313, 1327 ("The viability of this model derives from economic common sense. Only shareholders have strong incentives to maximize profits, thereby promoting economic efficiency.").

328. See Cory Dean Kandestin, The Duty to Creditors in Near-Insolvent Firms: Eliminating the 'Near-Insolvency' Distinction, 60 VAND. L. REV. 1235, 1242-43 ("Conversely, the only duties owed to creditors in a solvent corporation are contractual in nature. There is no recognized fiduciary duty that runs directly to creditors of a solvent corporation.").

329. Credit Lyonnais Bank Nederland, N.V. v. Pathe Communications Corp., No. 12150, 1991 WL 277613, at*34 (Del. Ch. Dec. 30, 1991). Of course, what is such an "insolvency" trigger can be "factually" difficult to determine, like in Credit Lyonnais, where the assets appeared ostensibly to be greater than the liabilities, but with the key asset a trial judgment subject to probable reversal on appeal. 
internally "abusive." ${ }^{330}$ I could further observe that from the perspective of "agency" principles, the principal/master, in "insolvency" situations, de facto obviously, at least partially, shifts from shareholders to creditors. However, if triggered, such Credit Lyonnais duties would not run strictly to creditors (or the preferred), but instead to the entire "community of interests" (meaning both shareholders and creditors). ${ }^{331}$ In this situation, Kraakman explains that a univocal duty would not produce firm "efficiency" incentives, since either side would opportunistically seek out self-interested solutions. ${ }^{332}$

Apart from duties, corporate law will mandatorily protect creditors, with the doctrines of piercing and reverse piercing, ${ }^{333}$ if the insiders use the corporation's limited liability shield in an internally "abusive" way. This is also a complicated matter. First, a shareholder's "limited liability" protection is an economic bedrock of the American corporation. ${ }^{334}$ On the other hand, taking "limited liability" too far with hard-core creditor "terrors" would undermine the "internal" corporate system, by over-deterring creditor contracting. This is also a complex issue. Hence, "[a]ccording to a famous remark by Benjamin Cardozo, piercing the veil is a doctrine 'enveloped in the mist of metaphor." ${ }^{335}$ My general common sense impression is that "piercing" is a fairly high standard, especially if the corporation complies with corporate "formalities," and so courts often will invoke "no piercing" holdings, reflecting a narrow economics oriented construction of "abuses" along the external axis, subject to some potential significant pockets of murkier common sense driven "activist" courts, who could conceivably invoke a broader construction of external "terrors." In rare cases, courts might have to confront an even more complex tort law creditor "piercing" calculation, with sharper "internalities" problems (with no fears of overdeterring creditor contracting and fears of over-deterring high utility small businesses with small pockets) as well as sharper "externalities" problems (with a bodily injured tort law victim who had no ex ante contractual

330. See Commentaries and Cases (Teacher's Manual), supra note 156, $§ 4.3$ ("Shareholders want to roll the dice because they get all the upside of winning in court but they can offload most of the downside from a bad outcome on the creditors, i.e., don't consider the externality that they are imposing on creditors.").

331. Credit Lyonnais, at *26 ("At least where a corporation is operating in the vicinity of insolvency, a board of directors is not merely the agent of the residue risk bearers, but owes its duty to the corporate enterprise.").

332. See Commentaries and Cases, supra note 156, § 4.3 (observing how both sides "selfishly" will not pick the highest "payoff" for all).

333. By all this, I mean holding personally liable either the controlling shareholders (piercing) or their affiliated companies (reverse piercing).

334. See Easterbrook \& Fischel, supra note 99.

335. Ventoruzzo, supra note 89 , at 151. 
choices). ${ }^{336}$

Another situation that might wake up corporate law in the protection of creditors is "equitable subordination," a doctrine that treats shareholder loans in "insolvency" situations as capital contributions, rather than debt, since the latter might potentially "dilute" the claims of pre-existing creditors. This is also a complex issue. On the one hand, those capital contributions make keep the firm afloat, but creditors again should not be over-deterred. Hence, equitable subordination is equally amorphous, as Ventoruzzo notes. ${ }^{337}$

For pro-creditor "distribution constraints," Delaware regulates creditor "terrorizing" dividends with the "nimble dividends" test. ${ }^{338}$

Beyond creditors, Delaware corporate social responsibility (CSR) laws also "mandatorily" require some basic degree of benevolence toward the "external" world, i.e., Delaware does not permit any exculpations for "knowing" illegalities, ${ }^{339}$ which, although perhaps "profitable" for the firm, would obviously sharply undermine the government and society.

Despite the lack of "mandatory" external axis duties in most situations, Delaware law does, at least outside Revlon mode, ${ }^{340}$ "recessively" permit managers in their discretion to consider the interests of "any" outside other corporate constituencies, if rationally related to shareholder interests. ${ }^{341}$ Hence, although "non-mandatory," one would expect that the insiders honoring the "external" axis to some extent would add corporate "good will" in many situations, thus facilitating corporate "internalities", in the big picture.

336. See Commentaries and Cases (Teacher's Manual), supra note 156, §4.4 ("So neither opinion [majority or dissent] is very satisfying: Either we go with the majority and create perverse incentives and inefficient enterprise; or we impose capital maintenance requirements, which we don't like very much for other reasons.") (analyzing Walkovsky v. Carlton, 18 N.Y.2d 414 (N.Y. 1966)).

337. Ventoruzzo, supra note 89, at 246.

338. See Commentaries and Cases, supra note 156156, § 4.2 .2 (comparing the Delaware "nimble dividends" test with the MBCA "insolvency" test).

339. See Del Code Ann. Tit. 8, § 102(b)(7) (carving out from charter exculpations "acts or omissions not in good faith or which involve intentional misconduct or a knowing violation of law").

340. See Revlon, Inc. v. MacAndrews \& Forbes Holdings, Inc., 506 A.2d 173, 182 (Del. 1986) (holding Revlon mode ending the power to have concern for "non-stockholder interests").

341. See Unocal v. Mesa Petroleum Co., 493 A.2d 946, 955 (Del. 1985) (stating that "[a] board may have regard for various constituencies in discharging its responsibilities, provided there are rationally related benefits accruing to the stockholders."). 